\title{
Development and optimization of an injectable formulation of copper diethyldithiocarbamate, an active anticancer agent
}

This article was published in the following Dove Press journal:

International Journal of Nanomedicine

31 May 2017

Number of times this article has been viewed

\author{
Mohamed Wehbe ${ }^{1,2}$ \\ Malathi Anantha' \\ Minghan $\mathrm{Shi}^{3,4}$ \\ Ada Wai-yin Leung' \\ Wieslawa H Dragowska' \\ Léon Sanche ${ }^{3,4}$ \\ Marcel B Bally 1,2,5,6 \\ 'Experimental Therapeutics, British \\ Columbia Cancer Agency, ${ }^{2}$ Faculty of \\ Pharmaceutical Sciences, University \\ of British Columbia, Vancouver, BC, \\ ${ }^{3}$ Department of Nuclear Medicine \\ and Radiobiology, Faculty of Medicine \\ and Health Science, ${ }^{4}$ Faculté de \\ médecine et des sciences de la santé, \\ Center for Research in Radiotherapy, \\ Department of Nuclear Medicine \\ and Radiobiology, Université de \\ Sherbrooke, Sherbrooke, Québec, \\ QC, ${ }^{5}$ Department of Pathology and \\ Laboratory Medicine, University of \\ British Columbia, ${ }^{6}$ Faculty of Medicine, \\ Center for Drug Research and \\ Development, Vancouver, BC, Canada
}

Correspondence: Mohamed Wehbe Faculty of Pharmaceutical Sciences, University of British Columbia, 675 West I0th Avenue Vancouver, BC V5Z IL3, Canada

Tel +l 6046758020

Fax + I 6046758183

Email Mwehbe@bccrc.ca
Abstract: Copper diethyldithiocarbamate $\left(\mathrm{Cu}(\mathrm{DDC})_{2}\right)$ is the active anticancer agent generated when disulfiram (DSF) is provided in the presence of copper. To date, research directed toward repurposing DSF as an anticancer drug has focused on administration of DSF and copper in combination, efforts that have proven unsuccessful in clinical trials. This is likely due to the inability to form $\mathrm{Cu}(\mathrm{DDC})_{2}$ at relevant concentrations in regions of tumor growth. Little effort has been directed toward the development of $\mathrm{Cu}(\mathrm{DDC})_{2}$, because of the inherent aqueous insolubility of the complex. Here, we describe an injectable $\mathrm{Cu}(\mathrm{DDC})_{2}$ formulation prepared through a method that involves synthesis of $\mathrm{Cu}(\mathrm{DDC})_{2}$ inside the aqueous core of liposomes. Convection-enhanced delivery of a $\mathrm{Cu}(\mathrm{DDC})_{2}$ formulation prepared using 1,2-distearoyl-sn-glycero-3-phosphocholine (DSPC)/cholesterol liposomes into a rat model of F98 glioma engendered a $25 \%$ increase in median survival time relative to vehicle-treated animals. In a murine subcutaneous MV-4-11 model, treatment resulted in a $45 \%$ reduction in tumor burden when compared to controls. Pharmacokinetic studies indicated that the $\mathrm{Cu}(\mathrm{DDC})_{2}$, was rapidly eliminated after intravenous administration while the liposomes remained in circulation. To test whether liposomal lipid composition could increase $\mathrm{Cu}(\mathrm{DDC})_{2}$ circulation lifetime, a number of different formulations were evaluated. Studies demonstrated that liposomes composed of DSPC and 1,2-distearoylsn-glycero-3-phosphoethanolamine-n-(carboxy[polyethylene glycol]-2000) (95:5) enhanced $\mathrm{Cu}(\mathrm{DDC})_{2}$ concentrations in the circulation as reflected by a 4.2 -fold increase in plasma $\mathrm{AUC}_{(0-\infty)}$ relative to the $\mathrm{DSPC} /$ cholesterol formulation. The anticancer activity of this $\mathrm{Cu}(\mathrm{DDC})_{2}$ formulation was subsequently evaluated in the MV-4-11 model. At its maximum tolerated dose, this formulation exhibited comparable activity to the DSPC/cholesterol formulation. This is the first report demonstrating the therapeutic effects of an injectable $\mathrm{Cu}(\mathrm{DDC})_{2}$ formulation in vivo.

Keywords: disulfiram, copper diethyldithiocarbamate, cancer, copper complexes, liposomes

\section{Introduction}

Disulfiram (DSF) is a US Food and Drug Administration (FDA)-approved drug for the treatment of alcoholism. It functions to inhibit acetaldehyde dehydrogenase 1, which in turn produces sensitivity to alcohol. ${ }^{1}$ DSF has recently become of interest in the treatment of human immunodeficiency virus and cancer through independent mechanisms..$^{2-6}$ This has sparked an interest in repurposing DSF for indications other than alcoholism, and our interest is focused on the potential of this drug or its metabolites for treating cancer.

A high-throughput chemical screen demonstrated that DSF was active against glioma stem cells, an activity that was substantially increased in the presence of copper (II). ${ }^{7}$ These results have been reported by others with a series of in vitro experiments 
highlighting this combinatorial effect. ${ }^{1,3,7,8}$ Although some publications have speculated that DSF and copper form a complex, ${ }^{3,9,10}$ studies in vitro and in vivo show that DSF is reduced to form a copper-binding ligand. ${ }^{11,12}$ Since DSF has been used clinically for over 60 years, the pharmacokinetic (PK) properties of the drug have been explored in depth. ${ }^{13}$ There have been reports of the formation of a copper complex in the stomach as a result of DSF conversion to diethyldithiocarbamate (DDC), a well-known copper chelator. ${ }^{14-18}$ Interestingly, copper diethyldithiocarbamate $\left(\mathrm{Cu}(\mathrm{DDC})_{2}\right)$ shows the same cytotoxic activity against gliomablastoma cells as when DSF and copper are administered concurrently. This suggests clearly that the copper complex of DDC is the therapeutically active agent. ${ }^{19,20} \mathrm{Cvek}$ et al have shown that $\mathrm{Cu}(\mathrm{DDC})_{2}$ acts as a proteosome inhibitor, ${ }^{21}$ specifically through binding to the 19S lid of the proteosome rather than the 20S subunit, which is targeted by bortezomib. ${ }^{22}$

Before developing any therapeutic application for $\mathrm{Cu}(\mathrm{DDC})_{2}$, there are formulation issues that need to be addressed if its use in vivo is to be evaluated. Specifically, the complex is a slightly soluble precipitate $(<0.1 \mathrm{mg} / \mathrm{mL})^{19}$ and, to date, there has not been any pharmaceutically appropriate formulations of $\mathrm{Cu}(\mathrm{DDC})_{2}$ suitable for in vivo use. We have previously described a method that solves the formulation issue: a method wherein the copper-complexation reaction occurs inside copper-containing liposomes. ${ }^{19}$ Here we demonstrate, for the first time, the anticancer activity of the resultant $\mathrm{Cu}(\mathrm{DDC})_{2}$ formulation. This method allows for the development of a parenterally suitable $\mathrm{Cu}(\mathrm{DDC})_{2}$ formulation and can take advantage of the well-established potential for liposomes to modulate the PK characteristics of an associated drug candidate. These $\mathrm{Cu}(\mathrm{DDC})_{2}$ formulations are the first of their kind to be used to assess the therapeutic potential of this interesting copper complex.

\section{Materials and methods Materials}

1,2-distearoyl-sn-glycero-3-phosphocholine (DSPC), Cholesterol (Chol), 1,2-distearoyl-sn-glycero-3-phosphoethanolamine-n-(carboxy[polyethylene glycol]-2000) $\left(\right.$ DSPE-PEG $_{2000}$ ), sphingomyelin (SM), 1,2-distearoylsn-glycero-3-phospho-(1'-rac-glycerol) (DSPG), and $3 \beta-\left(\mathrm{N}-\left[\mathrm{N}^{\prime}, \mathrm{N}^{\prime}\right.\right.$-dimethylaminoethane]-carbamoyl) cholesterol (DC-Chol) were purchased from Avanti Polar Lipids (Alabaster, AL, USA). Sephadex G-50 beads were purchased from GE healthcare (Uppsala, Sweden). ${ }^{3} \mathrm{H}$-cholesteryl hexadecyl ether $\left({ }^{3} \mathrm{H}-\mathrm{CHE}\right)$ and Pico-Fluor 40 scintillation cocktail were purchased from PerkinElmer Life Sciences
(Woodbridge, ON, Canada). Sodium diethyldithiocarbamate trihydrate, nigericin sodium salt, copper sulfate $\left(\mathrm{CuSO}_{4}\right)$, 4-(2-hydroxyethyl)-1-piperazineethanesulfonic acid (HEPES), and all other chemicals (reagent grade) were purchased from Sigma Aldrich (Oakville, ON, Canada).

\section{Liposome preparation}

The extrusion method for liposome preparation has been well documented by others. ${ }^{23}$ Briefly, for the Chol-containing formulations (DSPC/Chol (55:45), SM/Chol (55:45), DSPC/ DSPG/Chol/(70:20:10), or DSPC/DC-Chol/DSPE-PEG ${ }_{2000}$ (30:50:20)), the lipids were removed from the freezer and placed in a desiccator for $2 \mathrm{~h}$ before being weighed and dissolved in chloroform at the appropriate ratios. A nonexchangeable and nonmetabolizable lipid marker, ${ }^{3} \mathrm{H}-\mathrm{CHE}$, was incorporated into the chloroform mixture to achieve a specific activity of $\sim 0.025 \mu \mathrm{Ci} / \mathrm{mmol}$ total lipid. The solution was dried from chloroform using nitrogen gas and the thin film generated was further dried under high vacuum for $3 \mathrm{~h}$. The lipid film was then rehydrated at $65^{\circ} \mathrm{C}$ with unbuffered $300 \mathrm{mM} \mathrm{CuSO}_{4}$ (pH 3.5) or $300 \mathrm{mM} \mathrm{Cu-gluconate} \mathrm{(pH} \mathrm{3.5)} \mathrm{for} \mathrm{at} \mathrm{least} 2 \mathrm{~h}$. To prepare $\mathrm{Cu}(\mathrm{DDC})_{2}$ liposomes with final $\mathrm{Cu}(\mathrm{DDC})_{2}$-to-lipid ratios of 0.1 or 0.05 , copper salt solutions of 150 and $75 \mathrm{mM}$ were used. The resulting multilamellar vesicles underwent 5 freeze (in liquid nitrogen) and thaw $\left(65^{\circ} \mathrm{C}\right.$ water bath) cycles..$^{24}$ These were then placed in an extruder (Evonik Transffera Nanosciences, Vancouver, BC, Canada) and extruded through stacked $0.1 \mu \mathrm{m}$ polycarbonate filters at least 10 times at $65^{\circ} \mathrm{C}$. The size of the resulting liposomes was determined using quasi-electric light scattering (ZetaPals, Brookhaven Instruments Corporation, Holtsville, NY, USA).

For Chol-free formulations (DSPC/DSPE-PEG ${ }_{2000}$ or SM/DSPE-PEG ${ }_{2000}, 95: 5$ ), the indicated lipids were removed from the freezer and placed in a desiccator for at least $2 \mathrm{~h}$ before being weighed and dissolved in ethanol. ${ }^{3} \mathrm{H}-\mathrm{CHE}$ was incorporated in the dissolved lipids in ethanol. The final ethanol solution with dissolved lipids was added dropwise to a solution of $300 \mathrm{mM}$ unbuffered $\mathrm{CuSO}_{4}(\mathrm{pH} 3.5)$ in a $65^{\circ} \mathrm{C}$ water bath with constant mixing. The final ethanol concentration of the aqueous ethanol mixture was $\sim 15 \%(\mathrm{v} / \mathrm{v})$. This solution was then extruded using the same process as written above.

For all liposomal preparations the unencapsulated copper was removed by first exchanging the sample into a sucrose $(300 \mathrm{mM})$, HEPES $(20 \mathrm{mM})$, and EDTA (15 mM) buffer (SHE buffer, $\mathrm{pH} 7.4$ ) by passing the sample through a Sephadex G-50 column equilibrated with the buffer. The resulting solution was then dialyzed against a 
sucrose (300 mM) and HEPES (20 mM) buffer (SH buffer, $\mathrm{pH}$ 7.4) and concentrated to the desired concentration for experimental studies using tangential flow. Liposomal lipid concentration was determined by measuring ${ }^{3} \mathrm{H}-\mathrm{CHE}$ using liquid scintillation counting (Packard 1900TR Liquid Scintillation Analyzer).

\section{$\mathrm{Cu}(\mathrm{DDC})_{2}$ synthesis in liposomes}

Copper-loaded liposomes $\left(\mathrm{CuSO}_{4}\right.$ or $\mathrm{Cu}$-gluconate) were incubated with DDC in SH buffer at room temperature (unless indicated otherwise). Formation of $\mathrm{Cu}(\mathrm{DDC})_{2}$ was determined over a 60-min incubation period. Liposomeassociated $\mathrm{Cu}(\mathrm{DDC})_{2}$ was separated from unreacted DDC using a Sephadex G-50 column equilibrated with $\mathrm{SH}$ buffer. The liposome-containing fractions were analyzed to determine $\mathrm{Cu}(\mathrm{DDC})_{2}$-to-lipid ratios. Lipid concentrations were measured by liquid scintillation counting as described above and $\mathrm{Cu}(\mathrm{DDC})_{2}$ concentrations were determined by dissolving samples in methanol and measuring absorbance at $435 \mathrm{~nm}$ using a ultraviolet-visible (UV-Vis) spectrophotometer. Alternatively, a high-performance liquid chromatography (HPLC) assay was used where $\mathrm{Cu}(\mathrm{DDC})_{2}$ was measured on a Waters Alliance HPLC Module 2695 with a photodiode array detector (model 996) and the resulting chromatograms were analyzed by Empower 2 software. A Pronto SIL 120-3C18ace-EPS $(3.0 \mu \mathrm{m}, 4.6 \times 150 \mathrm{~mm})$ column was used with a mobile phase composed of $90 \%$ methanol and $10 \%$ water. A $100 \mu \mathrm{L}$ sample volume was injected, the flow rate was $1 \mathrm{~mL} / \mathrm{min}$, and column temperature was set to $40^{\circ} \mathrm{C}$. Only samples with $>90 \mathrm{ng} / \mathrm{mL}$ could be detected.

For studies involving the use of the potassium ionophore nigericin, the liposomes were prepared to contain $300 \mathrm{mM}$ $\mathrm{CuSO}_{4}$ and the external solution was exchanged with a buffer of KCl-Histidine (150 and $20 \mathrm{mM}$, pH 7.4). ${ }^{25}$ Nigericin was dissolved in DMSO and added to achieve $0.1 \mu \mathrm{g} / \mu \mathrm{mol} \mathrm{DSPC}$ and incubated at $60^{\circ} \mathrm{C}$ for $10 \mathrm{~min}$. DDC was then added to the nigericin-containing liposomes, and following formation of $\mathrm{Cu}(\mathrm{DDC})_{2}$ the solution was passed through Sephadex G-50 columns and analyzed as indicated above.

\section{$\mathrm{Cu}(\mathrm{DDC})_{2}$ dissociation from liposomes}

$\mathrm{Cu}(\mathrm{DDC})_{2}$-containing liposomes (final liposomal lipid concentration was $5 \mathrm{mM}$ ) were suspended in SH buffer with and without 50\% (v/v) fetal bovine serum (FBS) and incubated with constant mixing at $37^{\circ} \mathrm{C}$ in a water bath. At the indicated time points, $100 \mu \mathrm{L}$ of the solution was passed through a $1 \mathrm{~mL}$ Sephadex G-50 spin column equilibrated with $\mathrm{SH}$ buffer. The columns were centrifuged at $680 \times g$ for $3 \mathrm{~min}$ at $25^{\circ} \mathrm{C}$. The filtrate was assayed for $\mathrm{Cu}(\mathrm{DDC})_{2}$ using HPLC (see above) and lipid was determined by measuring of ${ }^{3} \mathrm{H}-\mathrm{CHE}$ using scintillation counting. For samples incubated with serum, an aliquot $(50 \mu \mathrm{L})$ was mixed with $950 \mu \mathrm{L}$ methanol, and the sample was then centrifuged at $10,000 \times g$ for $10 \mathrm{~min}$ at $4^{\circ} \mathrm{C}$ to pellet precipitated proteins. The supernatant was assayed for $\mathrm{Cu}(\mathrm{DDC})_{2}$ using HPLC.

\section{Cryo-transmission electron microscopy} Images were taken as previously described. ${ }^{26}$ Briefly, samples were prepared by applying $2-4 \mu \mathrm{L}$ of liposomes at $10-20 \mathrm{mg} / \mathrm{mL}$ total lipid to a glow-discharged standard electron microscopy copper grid. Excess liquid was removed from the grid by blotting and then the grid was submerged in liquid ethane to rapidly freeze the sample using a Mark IV Vitrobot system (FEI, Hillsboro, OR, USA). Images were taken under cryogenic conditions at a magnification of 55,000-100,000x with an AMT HR CCD bottom-mount camera. Samples were loaded with a Gatan $70^{\circ}$ cryo-transfer holder into an FEI G20 Lab6 200 kV (transmission electron microscope) TEM (FEI, Hillsboro, OR, USA) under low conditions with an underfocus of $1-4 \mu \mathrm{m}$ to enhance image contrast.

\section{Cell lines}

F98 rat glioblastoma cells were purchased from American Type Culture Collection (ATCC) (Manassas, VA, USA) and cultured in Dulbecco's Modified Eagle's Medium without FBS. MV-4-11 cell line was obtained from ATCC and maintained at $37^{\circ} \mathrm{C}$ and $5 \% \mathrm{CO}_{2}$ in Iscove's Modified Dulbecco's Medium (IMDM) (Thermo Fisher Scientific, Waltham, MA, USA) supplemented with 2 mM L-glutamine (Thermo Fisher Scientific) and 10\% FBS (Thermo Fisher Scientific). These cells carry activating mutations for the FLT3 gene due to rearrangements at $\mathrm{t}(4 ; 11)$. They are commonly used as a model of acute myeloid leukemia (AML) and can be established in immunocompromised mice (see below) as subcutaneous (sc) or systemic disease. All cell lines used are maintained in culture between passages 3 and 10. After the 10th passage we return to a stock supply of cells generated from the original ATCC cell line.

\section{Cytotoxicity assays}

For in vitro studies the MV-4-11 cells were seeded into 384well plates and allowed to grow for $24 \mathrm{~h}$ prior to addition of $\mathrm{Cu}(\mathrm{DDC})_{2}$ (prepared as described above or in DMSO, as indicated) at the indicated concentrations. At 24 or $72 \mathrm{~h}$ after drug addition, the cells were incubated with PrestoBlue ${ }^{\circledR}$ (Thermo Fisher Scientific) at a final concentration of 10\% v/v 
and $37^{\circ} \mathrm{C}$ for $1 \mathrm{~h}$. The fluorescence was measured at 560/590 $\mathrm{nm}$ excitation/emission.

\section{Western blot analysis for ubiquitinylated protein}

Cells were seeded in 6-well plates $(400,000$ cells per well) and treated with the $\mathrm{IC}_{30}$ of the indicated test compound for $24 \mathrm{~h}$. Cell lysates were prepared using lysis buffer comprising $50 \mathrm{mM}$ Tris- $\mathrm{HCl}$ (pH 7.4), $150 \mathrm{mM} \mathrm{NaCl}, 0.25 \%$ sodium deoxycholate, $1 \%$ NP-40, $0.1 \%$ sodium dodecyl sulfate, $1 \mathrm{mM}$ EDTA, and Mini Protease Inhibitor Cocktail tablets (Roche Diagnostics, QC, Canada) for $1 \mathrm{~h}$ on a shaker at $4{ }^{\circ} \mathrm{C}$. Cell lysates were centrifuged at $14,000 \times g$ for $10 \mathrm{~min}$ to collect total protein. A BCA Protein Assay Kit (Thermo Fisher Scientific) was used to determine protein concentrations and $10 \mu \mathrm{g}$ of lysates protein was run on a $4 \%-12 \%$ Bis-Tris gel (Thermo Fisher Scientific) at $170 \mathrm{~V}$ for $1 \mathrm{~h}$ before being transferred to a $0.2 \mu \mathrm{m}$ nitrocellulose membrane using the Trans-Blot Turbo Transfer System (Bio-Rad Laboratories, Hercules, CA, USA). The membranes were blocked with 5\% skim milk in TBST (20 mM Tris-base, 140 $\mathrm{mM} \mathrm{NaCl}, 0.1 \%$ Tween 20 ) and then probed for ubiquitin (Cell Signaling Technology, Danvers, MA, USA; 1:1,000) and $\beta$-Actin (Sigma-Aldrich, 1:50,000) overnight at $4^{\circ} \mathrm{C}$. Blots were then washed with TBST $(3 \times 5 \mathrm{~min})$ and incubated with horseradish peroxidase-conjugated secondary antibody (Promega, Madison, WI, USA) for $1 \mathrm{~h}$ at room temperature (1:10,000 for $\beta$-actin, 1:5,000 for ubiquitin). After washing with TBST ( $3 \times 5 \mathrm{~min})$, the blots were developed using Clarity Western ECL Substrate (Bio-Rad) for $5 \mathrm{~min}$ before imaging with the ChemiDoc MP Imaging System and ImageLab software (Bio-Rad).

\section{Flow cytometric analysis of $\mathrm{Cu}(\mathrm{DDC})_{2}-$ treated cells}

MV-4-11 cells were seeded in 6-well plates for $24 \mathrm{~h}$ and then treated with vehicle, $\mathrm{DDC}, \mathrm{CuSO}_{4}$, or $\mathrm{Cu}(\mathrm{DDC})_{2}(5 \mu \mathrm{M}$ final concentration). At $24 \mathrm{~h}$ post-treatment, cells were washed 3 times with cold Hanks Balanced Salt Solution (HBSS) and fixed in $70 \%$ ethanol. The final concentration of cells was adjusted to $10^{6} \mathrm{cells} / \mathrm{mL}$. The samples were left for $1 \mathrm{~h}$ on ice followed by an overnight incubation at $-20^{\circ} \mathrm{C}$. Cells were centrifuged and the pellet was stained using a PBS buffer containing $50 \mu \mathrm{g} / \mathrm{mL}$ propidium iodide (Thermo Fisher Scientific), $1 \mathrm{mg} / \mathrm{mL}$ RNase A (Sigma-Aldrich), and $0.1 \%$ Triton X-100 (Bio-Rad) for $15 \mathrm{~min}$ at $37^{\circ} \mathrm{C}$ followed by an incubation for $1 \mathrm{~h}$ on ice. Data were acquired and analyzed using a FACS Calibur flow cytometer and WINMDI 2.9 software, respectively.

\section{Reactive oxygen species assay}

The reactive oxygen species (ROS) assay was performed using the ROS-Glo ${ }^{\mathrm{TM}} \mathrm{H}_{2} \mathrm{O}_{2}$ Assay Kit (Promega) as per the manufacturer's instructions. Briefly, MV-4-11 cells were seeded at 14,000 cells/well in 96-well, white, clearbottom plates. Treatment was added subsequently along with $20 \mu \mathrm{L}$ substrate per well as per the supplier's protocol. Cells were treated with either menadione (positive control, $50 \mu \mathrm{M})$ or $\mathrm{Cu}(\mathrm{DDC})_{2}(200 \mu \mathrm{M})$ for $4 \mathrm{~h}$. All treatments were completed with and without cells to account for ROS generation as a result of interaction with vehicle and medium components. Finally, the $\mathrm{H}_{2} \mathrm{O}_{2}$ detection solution was added at $100 \mu \mathrm{L} /$ well and incubated at room temperature for $20 \mathrm{~min}$. ROS generation was measured based on luminescence signal using a FluorStar Optima plate reader.

\section{Ethics statement}

Studies involving the use of animals were completed under an Animal Care Protocol (A014-0290) approved by the University of British Columbia's (UBC's) Animal Care Committee. The health assessment of animals was completed using a standard operating procedure also approved by the UBC's Animal Care Committee.

\section{$\mathrm{Cu}(\mathrm{DDC})_{2}$ maximum tolerated dose}

To define the maximum tolerated dose (MTD) of $\mathrm{Cu}(\mathrm{DDC})_{2}$ formulations, mice $(n=3)$ were given an intravenous (iv) injection (lateral tail vein) of $\mathrm{Cu}(\mathrm{DDC})_{2}$ using a Monday, Wednesday, and Friday for 2 weeks (M, W, F ×2) dosing schedule. The health status of the animals was monitored following an established standard operating procedure. In particular, signs of ill health were based on body weight loss, change in appetite, and behavioral changes such as altered gait, lethargy, and gross manifestations of stress. When signs of severe toxicity were present, the animals were terminated (isoflurane overdose followed by $\mathrm{CO}_{2}$ asphyxiation) for humane reasons. Necropsy was performed to assess other signs of toxicity. The surviving animals were monitored for 2 weeks (14 days) after administration of the last dose and full necropsies were completed on all treated mice at that time to assess changes in tissue/organ appearance.

\section{$\mathrm{Cu}(\mathrm{DDC})_{2}$ pharmacokinetics studies}

$\mathrm{Cu}(\mathrm{DDC})_{2}$, synthesized in liposomes composed of DSPC/ Chol (55:45) or DSPC/DSPE-PEG 2000 (95:5), was injected intravenously at a dose of $15 \mathrm{mg} / \mathrm{kg}$ into CD-1 mice. At selected time points (eg, $0.25,0.5,1$, and/or $4 \mathrm{~h}$ ), mice ( $\mathrm{n}=3$ per time point) were terminated by isoflurane followed by 
$\mathrm{CO}_{2}$ asphyxiation and blood was collected by cardiac puncture. The blood was collected into EDTA-coated tubes kept on ice and centrifuged (Beckman Coulter Allegra X-15R) at $1,500 \times g$ for $15 \mathrm{~min}$ at $4^{\circ} \mathrm{C}$. Plasma was collected and placed into a separate tube before assaying for copper, $\mathrm{Cu}(\mathrm{DDC})_{2}$, and liposomal-associated lipid. The copper was measured using atomic absorption spectroscopy (AAS) by diluting plasma into $0.1 \% \mathrm{HNO}_{3}$. Plasma $(30 \mu \mathrm{L})$ was added to Pico-Fluor 40 scintillation cocktail and the amount of $\left[{ }^{3} \mathrm{H}\right]$ CHE was determined as described above. As a screening method to assess the effect of lipid composition on stability of the $\mathrm{Cu}(\mathrm{DDC})_{2}$ following administration, each unique formulation tested was administered intravenously at 15 $\mathrm{mg} / \mathrm{kg}$ in CD-1 mice ( $\mathrm{n}=4)$ and blood was collected at 30 min, processed as described above and then the plasma was assayed for copper, $\mathrm{Cu}(\mathrm{DDC})_{2}$, and liposomal lipid.

\section{Convection-enhanced delivery in F98 glioma model}

Male Fischer rats were purchased from Charles River Laboratories International Inc. (Wilmington, MA, USA). The implantation method was described previously. ${ }^{27} \mathrm{~F} 98$ cells $(10,000$ cells in $5 \mu \mathrm{L})$ were prepared and implanted into the right caudate nucleus $(1 \mathrm{~mm}$ anterior, $3 \mathrm{~mm}$ right of the bregma, and $6 \mathrm{~mm}$ deep) of the brain in $5 \mathrm{~min}$. The convection-enhanced delivery (CED) procedure ${ }^{28}$ was performed 10 days after implantation of F98 cells, at the same injection site using a 33 gauge Hamilton syringe. Before infusion, the burr was filled with bone wax and the needle was inserted $6.5 \mathrm{~mm}$ deep, retained there for $5 \mathrm{~min}$ and then withdrawn to $6 \mathrm{~mm}$. Test articles and a control vehicle to be injected were vehicle (SH Buffer), $\mathrm{CuSO}_{4}$ (300 mM)-DSPC/Chol liposomes (copper $0.1 \mathrm{mg} / \mathrm{mL}$, lipid $3.5 \mathrm{mg} / \mathrm{mL}$ ), or $\mathrm{Cu}(\mathrm{DDC})_{2}$ formulated in DSPC/Chol liposomes $(0.5 \mathrm{mg} / \mathrm{mL}$, lipid $3.5 \mathrm{mg} / \mathrm{mL})$. A total volume of $10 \mu \mathrm{L}$ was infused at an infusion rate of 0.5 $\mu \mathrm{L} / \mathrm{min}$ for $20 \min \left(5 \mu \mathrm{g} \mathrm{Cu}(\mathrm{DDC})_{2}\right.$ per rat). After the infusion, the needle was left in, to reduce backflow and increase convection volume, for $5 \mathrm{~min}$ prior to being withdrawn.

\section{$\mathrm{Cu}(\mathrm{DDC})_{2}$ efficacy studies in the MV-4-I I sc tumor model}

As indicated above, MV-4-11 cells used for sc implantation were between passages 3 and 10 and were always collected when maintained at a confluence of $80 \%-90 \%$ at the time of harvesting for implantation. RAG-2M mice (up to 9 per group) were inoculated with $1 \times 10^{6}$ cells in an injection volume of $50 \mu \mathrm{L}$ per animal using a 28 -gauge needle. Treatment was initiated on day 12 and treatment included the vehicle control (SH buffer), copper liposomes, or $\mathrm{Cu}(\mathrm{DDC})_{2}$ prepared in liposomes composed of either DSPC/Chol (55:45) or DSPC/

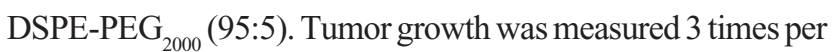
week with calipers and tumor volumes were calculated based on a formula of $\left(\mathrm{L} \times \mathrm{W}^{2}\right) / 2$. The humane endpoint for these studies was defined when tumors exceeded $800 \mathrm{~mm}^{3}$. Animals with nondetectable tumors by day 25 were excluded.

\section{Statistical analysis}

All data are plotted using the Prism 6.0 software (GraphPad) as mean \pm standard error of the mean (SEM) or mean \pm $\mathrm{SD}$ as described in the Figure legends. Statistical analyses comparing $\mathrm{Cu}(\mathrm{DDC})_{2}$ plasma levels or tumor growth studies were performed using one-way analysis of variance (ANOVA) followed by Tukey's adjustments to correct for multiple comparisons. A $P$-value $<0.05$ was considered statistically significant. Survival study statistical analysis was performed using the log rank test, and a $P$-value $<0.05$ was considered statistically significant.

\section{Results $\mathrm{Cu}(\mathrm{DDC})_{2}$ characterization}

A general method for preparing metal-complexed drug candidates has been disclosed recently. ${ }^{19}$ One of the examples disclosed in this previous publication included the use of DSPC/Chol (55:45) liposomes, prepared in $300 \mathrm{mM}$ copper sulfate, as nano-scale reaction vessels for the synthesis of $\mathrm{Cu}(\mathrm{DDC})_{2}$. This process solved solubility issues because the highly insoluble complex was formed when the ligand was added to the outside of copper-containing liposomes. This synthesis reaction (Figure 1A) was completed at $25^{\circ} \mathrm{C}$ within 5 min and was easily detected by eye as the absorbance of the solution changed to exhibit a broad peak around $435 \mathrm{~nm}$. The resultant product appeared stable, as the reaction could be carried out for $1 \mathrm{~h}$ with no significant change in the $\mathrm{Cu}(\mathrm{DDC})_{2}-$ to-lipid ratio (Figure 1B). The $\mathrm{Cu}(\mathrm{DDC})_{2}$ formulation showed negligible dissociation from the liposomes in vitro when the samples were incubated at $37^{\circ} \mathrm{C}$ over $72 \mathrm{~h}$ in a solution containing 50\% FBS in SH buffer (pH 7.4; Figure 1C). The in vitro activity of this novel formulation of $\mathrm{Cu}(\mathrm{DDC})_{2}$ was compared to the complex prepared in the absence of liposomes and dissolved in DMSO, by generating dose-response curves against MV-4-11 leukemia cells (Figure 1D). The 72-h $\mathrm{IC}_{50}$ determined for both formulations were identical $(\sim 0.11 \mu \mathrm{M})$; however, in contrast to the DMSO-solubilized $\mathrm{Cu}(\mathrm{DDC})_{2}$ there was no evidence of precipitates in the incubation wells when $\mathrm{Cu}(\mathrm{DDC})_{2}$ was added as the liposomal formulation. 
A

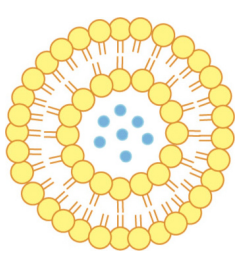

Cu-LNP

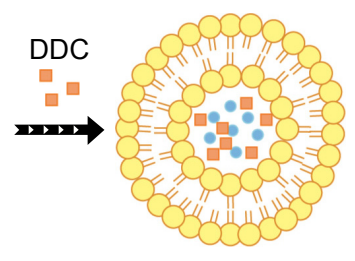

$\mathrm{Cu}^{2+}+\mathrm{DDC}$

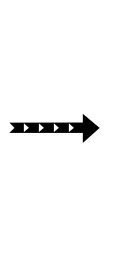

$\mathrm{Cu}(\mathrm{DDC})_{2}$-LNP

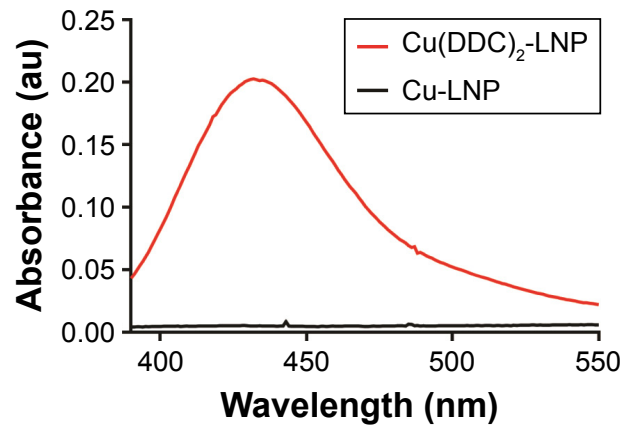

B
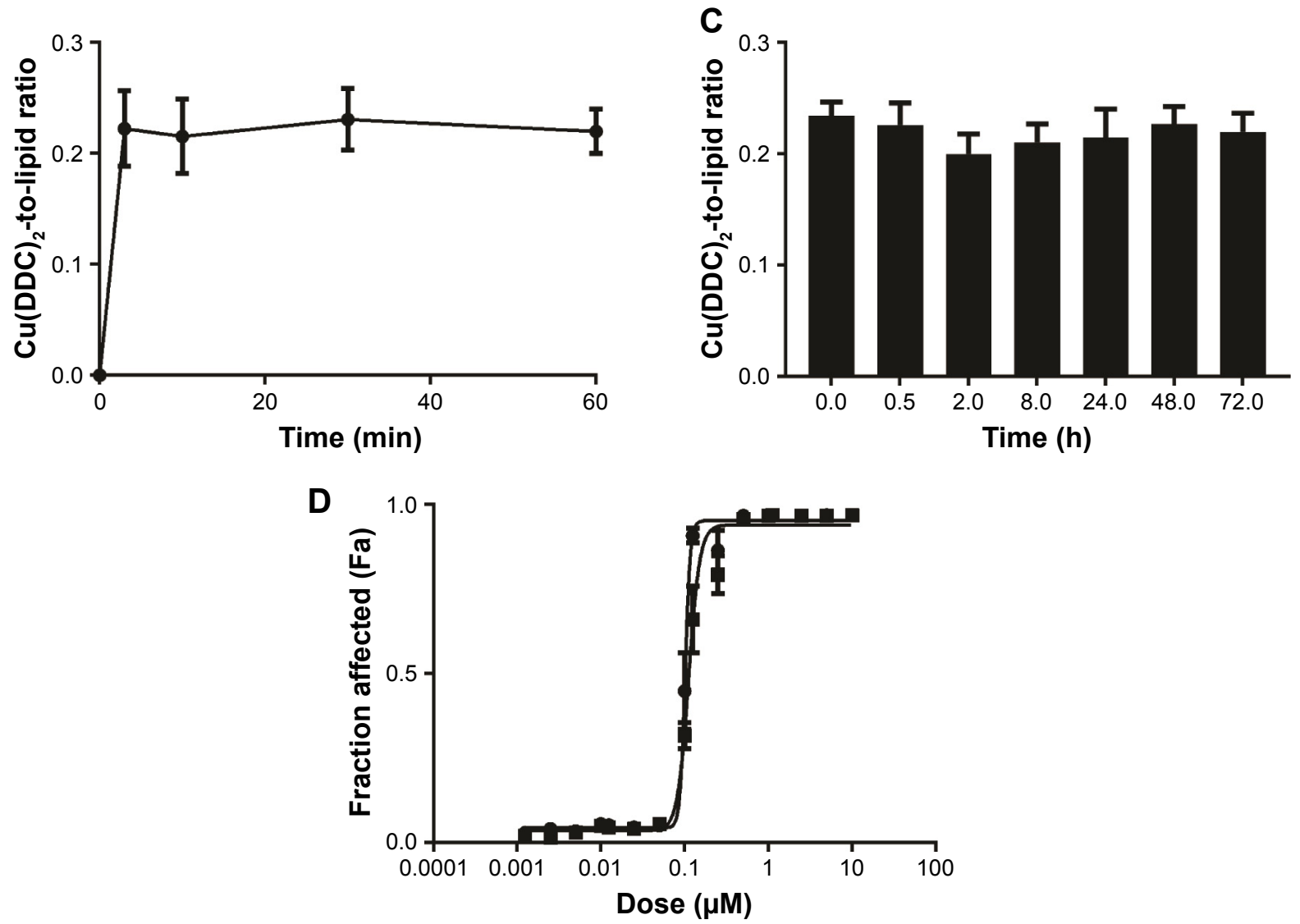

Figure I Characterization of $\mathrm{Cu}(\mathrm{DDC})_{2}$ prepared in a liposomal formulation (DSPC/Chol $(55: 45)$ ) wherein the Cu(DDC), was synthesized inside the copper-containing liposomes.

Notes: (A) Schematic representation of $\mathrm{Cu}(\mathrm{DDC})_{2}$ complex formation inside copper liposomes upon addition of DDC. Cu-liposomes and Cu(DDC) ${ }_{2}$-liposomes were scanned on a UV-Vis spectrophotometer, and the formation of $\mathrm{Cu}(\mathrm{DDC})_{2}$ results in a peak at $435 \mathrm{~nm}$ indicative of complex formation. (B) Formation of $\mathrm{Cu}(\mathrm{DDC})_{2}$ inside DSPC/Chol liposomes (final liposomal lipid concentration was $20 \mathrm{mM}$ ) as a function of time over $\mathrm{I} h$ at $25^{\circ} \mathrm{C}$ following addition of DDC to the liposomes at a final DDC-tolipid ratio of 0.4. (C) $\mathrm{Cu}(\mathrm{DDC})_{2}$, release from DSPC/Chol (55:45) liposomes over a 72 -h time course in the presence of $50 \% \mathrm{FBS}$ at $37^{\circ} \mathrm{C}$. Cu(DDC) ${ }_{2}$ was measured using a UV-Vis spectrophotometric assay and lipid was measured through use of a radioactive lipid marker $\left({ }^{3} \mathrm{H}-\mathrm{CHE}\right)$. (D) MV-4-II cytotoxicity curves for Cu(DDC) ${ }_{2}$ dissolved in DMSO (匹) and the $\mathrm{Cu}(\mathrm{DDC})_{2}$ liposomal preparation $(\bullet)$ where cell viability was measured (using PrestoBlue) following a 72 -h exposure to the added $\mathrm{Cu}(\mathrm{DDC})$. Data are presented as mean \pm standard error of the mean of 3 experiments. If error bars are not seen then they are within the size of the symbol used.

Abbreviations: Chol, cholesterol; DDC, diethyldithiocarbamate; DSPC, distearoyl-sn-glycero-3-phosphocholine; FBS, fetal bovine serum; ${ }^{3} \mathrm{H}$-CHE, ${ }^{3} \mathrm{H}$-cholesteryl hexadecyl ether; UV-Vis, ultraviolet-visible; DMSO, dimethyl sulfoxide.

\section{Studies to assess the mechanism of $\mathrm{Cu}(\mathrm{DDC})_{2}$ activity}

Previous publications, ${ }^{21,29}$ indicated that the mechanism of DDC cytotoxicity was mediated, at least in part, through proteosome inhibition. Proteosome inhibitors, such as the FDA-approved bortezomib, have been used for the treatment of acute myeloid leukemia. ${ }^{30}$ For this reason, we used the acute myeloid leukemia MV-4-11 cell line to characterize the cytotoxicity of $\mathrm{Cu}(\mathrm{DDC})_{2}$ prepared within $\mathrm{DSPC} /$ Chol liposomes. The $\mathrm{IC}_{50}$ determined using PrestoBlue (see Methods) of $\mathrm{Cu}(\mathrm{DDC})_{2}$ at 24 and $72 \mathrm{~h}$ was 0.42 and $0.11 \mu \mathrm{M}$, respectively (Figure $2 \mathrm{~A}$ and $\mathrm{B}$ ). To determine whether $\mathrm{Cu}$ (DDC) $)_{2}$ inhibits the proteosome, MV-4-11 cells were treated with vehicle, $\mathrm{CuSO}_{4}$, or $\mathrm{Cu}(\mathrm{DDC})_{2}$, and the 

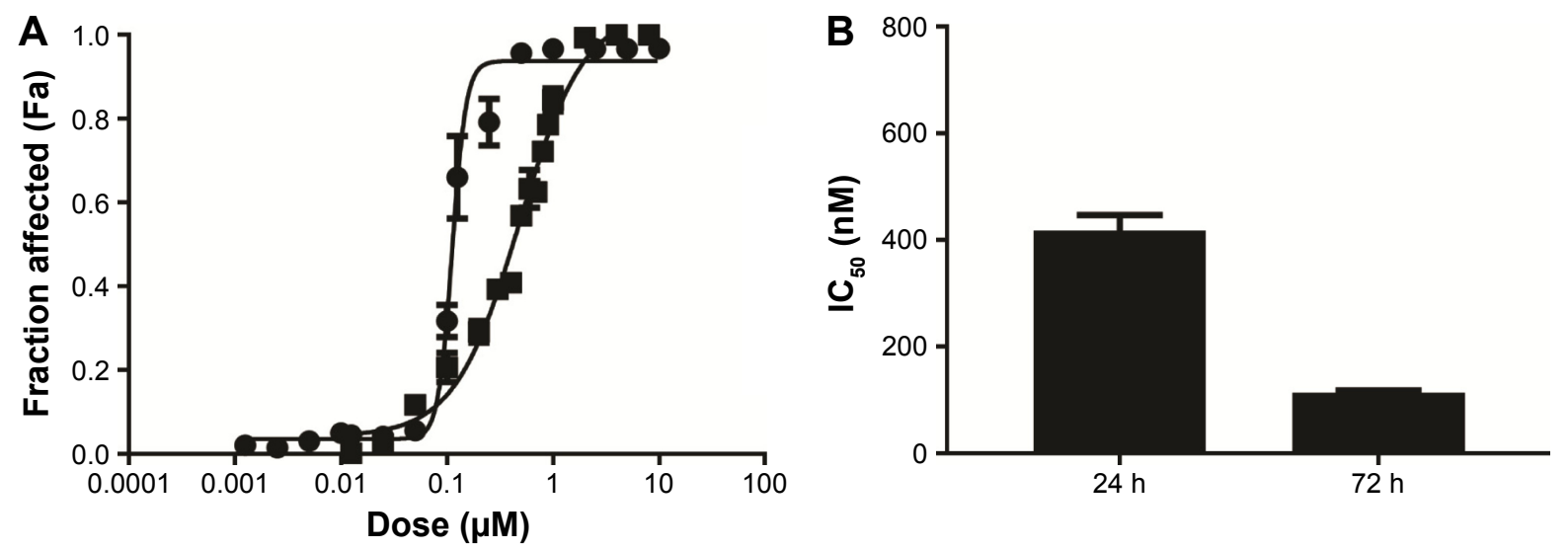

C

$0 \frac{\mathrm{CuSO}_{4}}{300600} \frac{\mathrm{Cu}(\mathrm{DDC})_{2}}{150300 \mathrm{nM}}$

D
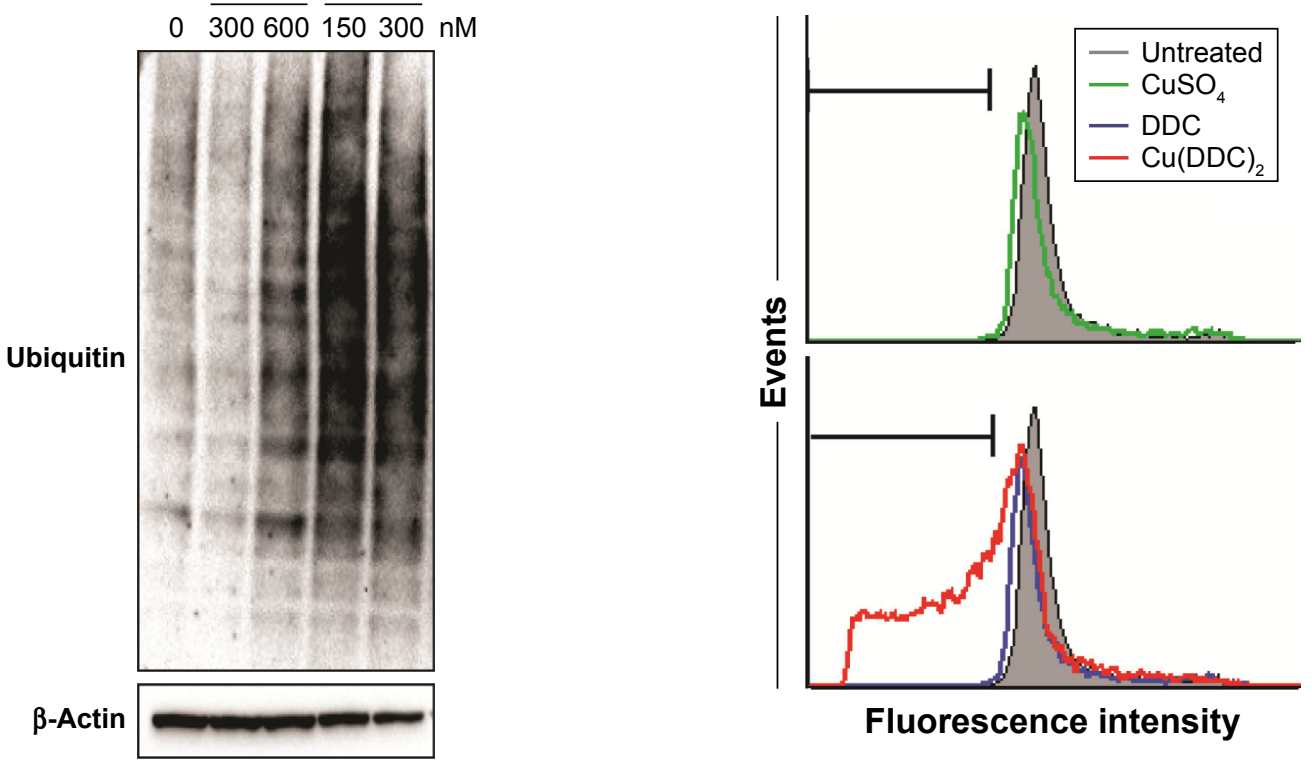

Fluorescence intensity

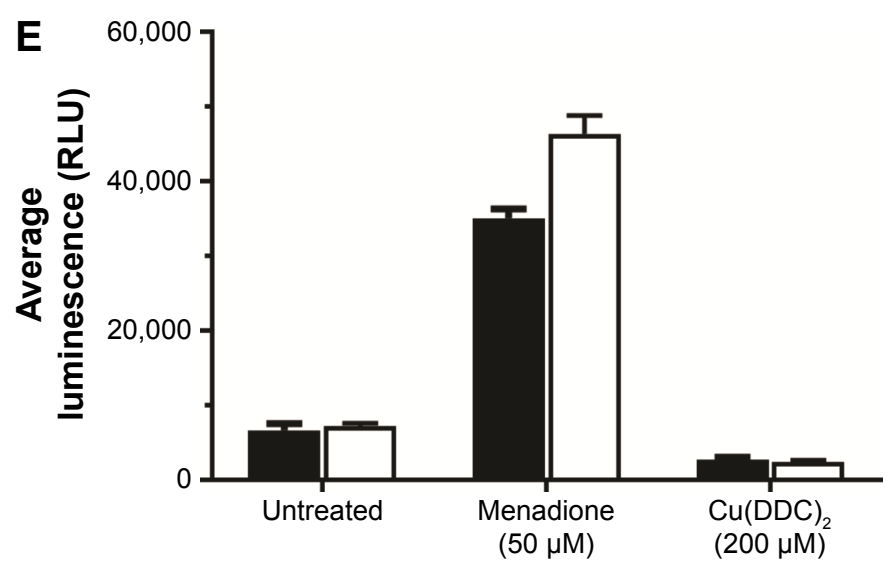

Figure $2 \mathrm{Cu}(\mathrm{DDC})_{2}$ acts primarily as a proteosome inhibitor and induces cell death in MV-4-II cells.

Notes: (A) Cytotoxicity curves generated when MV-4-II cells are exposed to $\mathrm{Cu}(\mathrm{DDC})_{2}$ (prepared inside DSPC/Chol liposomes) for either $24(\mathbf{\square})$ or $72(\bullet) \mathrm{h}$ where viability was measured using PrestoBlue. (B) The $\mathrm{IC}_{50}$ values of MV-4-II cells that were treated with $\mathrm{Cu}(\mathrm{DDC})_{2}$ for 24 and $72 \mathrm{~h}$. The proteasome inhibition activity was determined as described in the Methods using MV-4-II cells treated with the indicated doses of $\mathrm{CuSO}_{4}$ or $\mathrm{Cu}(\mathrm{DDC})_{2}$ (prepared inside DSPC/Chol liposomes) for $24 \mathrm{~h}$. (C) Proteasome inhibition resulted in accumulation of ubiquitinated proteins presented as long dark bands on the Western blot following $\mathrm{Cu}(\mathrm{DDC})$, treatment (I50 and $300 \mathrm{nM}$ ) but not for vehicle or $\mathrm{CuSO}_{4}(300-600 \mathrm{nM})$. (D) Cell-cycle analyses were completed using MV-4-II cells treated with CuSO ${ }_{4}$, DDC, or Cu(DDC) ${ }_{2}$ for $24 \mathrm{~h}$ and the results indicated no significant change in the cell cycle upon $\mathrm{Cu}(\mathrm{DDC})_{2}$ exposure. There was an increase in the sub $\mathrm{G}_{0} / \mathrm{G}_{1}$ fraction (marked with horizontal bar) when cells were treated with $\mathrm{Cu}(\mathrm{DDC})_{2}$, indicative of cell death as evident by DNA fragmentation. (E) ROS formation was tested in MV-4-II cells treated with $\mathrm{Cu}(\mathrm{DDC})_{2}(\mathrm{Prepared}$ inside DSPC/Chol liposomes), where ROS formation was measured $4 \mathrm{~h}$ following initiation of treatment. $\mathrm{Cu}(\mathrm{DDC})_{2}$ treatment did not induce ROS formation. Menadione was used as a positive control and ROS formation in the cells was evident by a statistically significant difference in luminescence relative to the corresponding cell-free condition. Data are presented as mean \pm standard error of the mean of 3 experiments.

Abbreviations: Chol, cholesterol; DDC, diethyldithiocarbamate; DSPC, distearoyl-sn-glycero-3-phosphocholine; ROS, reactive oxygen species. 
accumulation of ubiquitinylated proteins, a marker of proteosome inhibition, was subsequently measured via Western blotting. Only the $\mathrm{Cu}(\mathrm{DDC})_{2}$-treated groups showed marked accumulation of ubiquinylated protein relative to the controls (Figure 2C). To further investigate mechanisms involved in $\mathrm{Cu}(\mathrm{DDC})_{2}$ cytotoxicity, we performed cell-cycle analysis using flow cytometry (see Methods). The results showed no significant changes in the cell cycle after $24 \mathrm{~h}$ of $\mathrm{Cu}(\mathrm{DDC})_{2}$ exposure. However, $\mathrm{Cu}(\mathrm{DDC})_{2}$ caused an increase in the sub $\mathrm{G}_{0} / \mathrm{G}_{1}$ phase indicative of cell death (Figure $2 \mathrm{D}$ ). As some published reports have suggested that $\mathrm{Cu}(\mathrm{DDC})_{2}$ treatment leads to production of ROS, ${ }^{22}$ we also evaluated whether $\mathrm{Cu}(\mathrm{DDC})_{2}$ induces cell death via this mechanism. Cells were treated for $4 \mathrm{~h}$ with $\mathrm{Cu}(\mathrm{DDC})_{2}$ or menadione (positive control). The results showed that $\mathrm{Cu}(\mathrm{DDC})_{2}$ treatment did not result in ROS generation (Figure 2E), suggesting that it is unlikely to be an important mechanism of cytotoxicity for the formulation described here.

\section{Plasma elimination of $\mathrm{Cu}(\mathrm{DDC})_{2}$ prepared in DSPC/Chol (55:45) liposomes}

The $\mathrm{Cu}(\mathrm{DDC})_{2}$ formulation prepared as described above was suitable for iv administration. To assess $\mathrm{Cu}(\mathrm{DDC})_{2}$ elimination from plasma, mice were given a single iv dose $(15 \mathrm{mg} / \mathrm{kg})$ of $\mathrm{Cu}(\mathrm{DDC})_{2}$ and plasma samples were collected as described in the Methods. Attempts to measure $\mathrm{Cu}(\mathrm{DDC})_{2}$ in the plasma compartment were, however, unsuccessful even when using a 15 min time point. The $\mathrm{Cu}(\mathrm{DDC})_{2}$ levels were below the detection limits of our HPLC assay $(0.09 \mu \mathrm{g} / \mathrm{mL})$. Plasma copper levels were measurable by AAS, and in
$\mathrm{Cu}(\mathrm{DDC})_{2}$-treated mice these levels were above the level of copper determined in plasma collected from untreated mice. For this reason, we used plasma copper levels (after subtraction of control plasma copper levels) as a surrogate marker of $\mathrm{Cu}(\mathrm{DDC})_{2}$. The results, summarized in Figure 3, indicate that the percent of the injected copper dose remaining in plasma was $5.2 \%$ at $15 \mathrm{~min}$, indicative of $95 \%$ eliminations of the injected $\mathrm{Cu}(\mathrm{DDC})_{2}$ (Figure 3A; filled circles). This value decreased to $0.25 \%$ of the injected dose $1 \mathrm{~h}$ after administration. In contrast, 15 min after administration of the formulation, 93\% of the injected liposomal lipid dose was still in the plasma compartment, a value that decreased to $80 \% 1 \mathrm{~h}$ following administration (Figure $3 \mathrm{~A}$, open circles). The liposomal lipid elimination rate was comparable to that described previously for DSPC/Chol liposomes. ${ }^{31}$

These results suggest that $\mathrm{Cu}(\mathrm{DDC})_{2}$ prepared inside DSPC/Chol liposomes does not remain inside the liposomes following iv dosing. This result was surprising given the stability of the formulation as determined using in vitro methods (Figure 1). Loss of associated $\mathrm{Cu}(\mathrm{DDC})_{2}$ from the liposomes after administration is highlighted by the copper-to-lipid ratio data (Figure 2B). Prior to injection, this ratio was 0.25 (time 0 ), but it drops to 0.02 after $15 \mathrm{~min}$. This is indicative of $92 \%$ loss of $\mathrm{Cu}(\mathrm{DDC})_{2}$ from the liposomes within 15 min after injection. In contrast, $1 \mathrm{~h}$ after administration of uncomplexed $\mathrm{CuSO}_{4}$ containing DSPC/Chol liposomes, the copper-to-lipid ratio suggested $>90 \%$ retention of the encapsulated copper. This is indicative of $\mathrm{Cu}(\mathrm{DDC})_{2}$ being released from the liposomes as the copper complex, whereas uncomplexed $\mathrm{Cu}^{2+}$ ions are, as expected, retained in the liposomes owing to their charge. It can be suggested that the
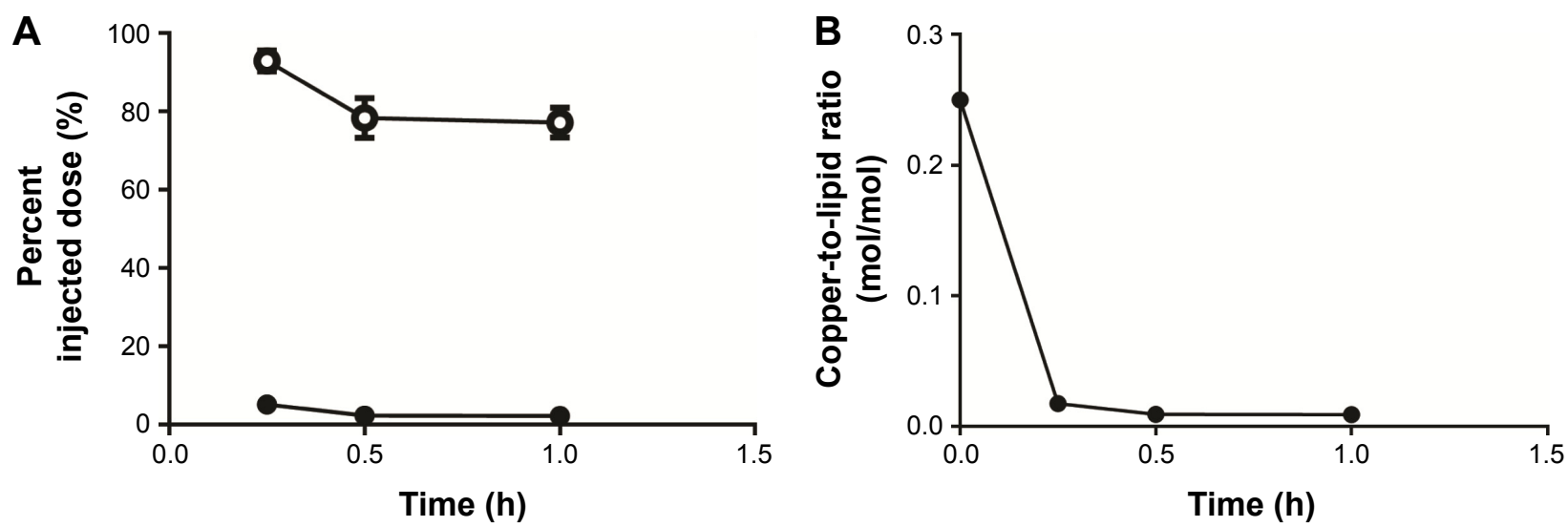

Figure $3 \mathrm{Cu}(\mathrm{DDC})_{2}$ (prepared in DSPC/Chol (55/45) liposomes) elimination after intravenous (iv) injection in CD-I mice.

Notes: (A) The percent injected dose of copper (-•-) was measured using AAS as a surrogate for $\mathrm{Cu}(\mathrm{DDC})_{2}$. The percent injected dose of liposomal lipid (-o-) was measured by assessing ${ }^{3} \mathrm{H}-\mathrm{CHE}$ as a nonexchangeable, nonmetabolizable liposomal lipid marker. (B) The decrease in copper-to-lipid ratio suggests that the Cu(DDC) ${ }_{2}$ prepared inside the liposome dissociated from the liposomes within 15 min. All data are plotted as mean \pm standard error of the mean ( $n=4$ per time point); if the error bars are not visible then the error bars are within the size of the symbol used.

Abbreviations: AAS, atomic absorption spectroscopy; Chol, cholesterol; DDC, diethyldithiocarbamate; DSPC, distearoyl-sn-glycero-3-phosphocholine; ${ }^{3} \mathrm{H}-\mathrm{CHE},{ }^{3} \mathrm{H}$-cholesteryl hexadecyl ether. 

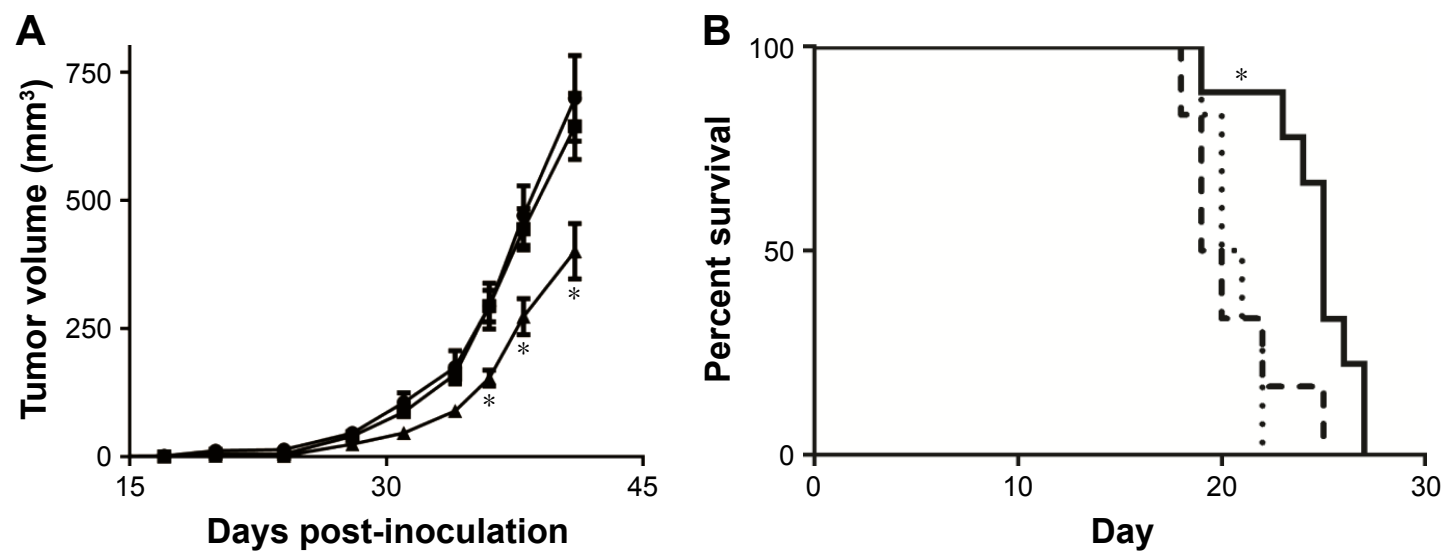

Figure $4 \mathrm{Cu}(\mathrm{DDC})_{2}$ efficacy studies.

Notes: (A) MV-4-II cells $\left(I \times 10^{6}\right)$ were inoculated subcutaneously into RAG-2M mice and the tumors were treated intravenously with vehicle (SH buffer, $\bullet$ ), coppercontaining liposomes $(1.3 \mathrm{mg} / \mathrm{kg}, \boldsymbol{-})$ or $\mathrm{Cu}(\mathrm{DDC})_{2}(8 \mathrm{mg} / \mathrm{kg}, \boldsymbol{\Delta})$ formulated in DSPC/Chol liposomes using a $\mathrm{M}, \mathrm{W}, \mathrm{F} \times 2 \mathrm{dosing}$ schedule. Tumor volumes were measured 3 times a week and are plotted as mean \pm standard error of the man (up to 9 mice per group). As shown, there was a significant delay in tumor growth when comparing tumor sizes in animals that were treated with $\mathrm{Cu}(\mathrm{DDC})_{2}$ to those treated with the vehicle control. "** indicates statistically significant difference $(P<0.05)$ upon statistical analysis using a two-way analysis of variance followed by Tukey's adjustments to correct for multiple comparisons. (B) The activity of Cu(DDC) 2 (prepared in DSPC/Chol liposomes) was evaluated following $\mathrm{CED}$ of $\mathrm{Cu}(\mathrm{DDC})_{2}$ in a rat glioma model wherein 10,000 F98 cells were implanted intracranially into the right caudate nucleus. A single $10 \mu \mathrm{L}$ injection of vehicle (SH buffer, $\cdots \cdot)$, copper liposomes $(0.08 \mathrm{mg} / \mathrm{mL},--)$, or $\mathrm{Cu}(\mathrm{DDC}),(0.5 \mathrm{mg} / \mathrm{mL}$, -$)$ was injected 10 days after F98 implantation ( $\mathrm{n}=9)$. Survival study statistical analysis was performed using the log rank test with GraphPad Prism 6. *A P-value under 0.05 was considered statistically significant.

Abbreviations: Chol, cholesterol; CED, Convection-enhanced delivery; DDC, diethyldithiocarbamate; DSPC, distearoyl-sn-glycero-3-phosphocholine; M, W, F ×2, Monday, Wednesday, and Friday for 2 weeks; SH, sucrose HEPES.

DSPC/Chol liposomal formulation of $\mathrm{Cu}(\mathrm{DDC})_{2}$ addresses the solubility challenges of this compound, but because the complex is released rapidly from the liposomes following administration it should be noted that the liposomes are not behaving as drug delivery vehicles.

\section{$\mathrm{Cu}(\mathrm{DDC})_{2}$ efficacy in models of cancer}

The results thus far demonstrate that $\mathrm{Cu}(\mathrm{DDC})_{2}$, synthesized in liposomes remains in solution in a form that could be safely administered intravenously. The potential for using the resultant product as an anticancer drug was measured in 2 different rodent models of cancer, and the results are summarized in Figure 4. The activity of $\mathrm{Cu}(\mathrm{DDC})_{2}$ (prepared in DSPC/Chol liposomes) was measured in mice with established sc tumor models generated following sc injection of the MV-4-11 cells (Figure 4A). Before assessing activity, the MTD of $\mathrm{Cu}(\mathrm{DDC})_{2}$ was determined in tumor-free $\mathrm{CD}-1$ mice (see Methods). Given the rapid elimination of $\mathrm{Cu}(\mathrm{DDC})_{2}$ following iv injection (Figure 3), we selected a dose-intense schedule where the animals were injected iv on Monday, Wednesday, and Friday for 2 weeks $(\mathrm{M}, \mathrm{W}, \mathrm{F} \times 2)$. Using this schedule the MTD of $\mathrm{Cu}(\mathrm{DDC})_{2}$ was determined to be $8 \mathrm{mg} / \mathrm{kg}$. At doses $>8 \mathrm{mg} / \mathrm{kg}$ (eg, $15 \mathrm{mg} / \mathrm{kg}$ ) the animals were terminated at humane endpoints ( 5 days following initial treatment). On necropsy, these animals showed no obvious changes in tissue or organ appearance other than the occasional enlarged spleen and discoloration of the liver and kidney. It should be noted that extravasation injuries (at the site of injection) were observed with some mice. If the extravasation injury was considered severe, then the mouse was terminated for ethical reasons and that animal was excluded from the treatment group. For animals with established MV-4-11 sc tumors, dosing began on day 12 when mice were injected (iv) with vehicle ( $\mathrm{SH}$ buffer), DSPC/Chol (55:45)-copper sulfate liposomes (1.3 mg copper $/ \mathrm{kg}$ ), or $\mathrm{Cu}(\mathrm{DDC})_{2}$ prepared in $\mathrm{DSPC} / \mathrm{Chol}$ liposomes $\left(8 \mathrm{mg} \mathrm{Cu}(\mathrm{DDC})_{2} / \mathrm{kg}\right.$, copper dose $1.3 \mathrm{mg} / \mathrm{kg}$ ), respectively. The liposomal lipid dose was $\sim 50 \mathrm{mg} / \mathrm{kg}$. Tumor size was measured over time (see Methods). The results (Figure 4A) suggest that tumor growth was comparable in animals treated with the vehicle and the copper-containing liposome control. The $\mathrm{Cu}(\mathrm{DDC})_{2}$ (prepared in DSPC/Chol liposomes)-treated animals exhibited a delay in tumor growth rate. Animals in this group showed a $45 \%$ reduction in tumor volume when compared to the vehicle- and copper-treated animals on day 41. Although there was a treatment-engendered delay in tumor growth when using the MV-4-11 sc tumor model, the results suggested that $\mathrm{Cu}(\mathrm{DDC})_{2}$ activity was unremarkable on the basis of RECIST criteria ${ }^{32}$ where notable activity is reflected by stable disease, a partial response, or a complete response. For this reason, we choose to assess $\mathrm{Cu}(\mathrm{DDC})_{2}$ (prepared in DSPC/Chol liposomes) in an orthotopic F98 (rat glioblastoma) model, where treatment was administered directly into the site of tumor inoculation by CED. ${ }^{28}$ The glioblastoma line was of interest because previous publications suggested that DSF and its metabolite DDC in the presence 
of copper were particularly active against glioblastoma cells. ${ }^{3,33}$ As noted in the supplementary data (Figure S1), the in vitro activity of $\mathrm{Cu}(\mathrm{DDC})_{2}$ against $\mathrm{U} 251 \mathrm{MG}$ and F98 cell lines was comparable to that observed for the MV-4-11 cells (Figure 1). The 72-h $\mathrm{IC}_{50}$ of $\mathrm{Cu}(\mathrm{DDC})_{2}$ was 384 and $417 \mathrm{nM}$ for U251 MG cells and F98 cells, respectively. The in vivo efficacy of $\mathrm{Cu}(\mathrm{DDC})_{2}$ (prepared in $\mathrm{DSPC} / \mathrm{Chol}$ liposomes) was evaluated in the F98 rat glioma model where each rat was injected at the site of tumor cell inoculation with a $0.5 \mathrm{mg} / \mathrm{mL}$ solution of $\mathrm{Cu}(\mathrm{DDC})_{2}$, the vehicle- or copper-containing liposomes $(0.08 \mathrm{mg} / \mathrm{mL})$ (see Methods). This was defined as the MTD of the $\mathrm{Cu}(\mathrm{DDC})_{2}$ formulation when administered by CED methods. In these studies, control animals exhibited a median survival time (MST) of 20.5 and 19.5 days, respectively (Figure 4B). In animals treated with $\mathrm{Cu}(\mathrm{DDC})_{2}$, the MST increased to 25 days (a 25\% increase in MST). The difference between the MST of those animals treated with the controls and $\mathrm{Cu}(\mathrm{DDC})_{2}$ was statistically significant $(P<0.05)$ and comparable to previous studies demonstrating a $11.3 \%$ increase in MST when the F98 glioblastoma model rats were treated with lipoplatin (a liposomal formulation of cisplatin). ${ }^{28}$

\section{Enhancing the circulation longevity of $\mathrm{Cu}(\mathrm{DDC})_{2}$}

Although the results presented thus far suggest that the $\mathrm{Cu}(\mathrm{DDC})_{2}$ formulation prepared in $\mathrm{DSPC} / \mathrm{Chol}$ liposomes is therapeutically active, a significant advantage of the technology used here to create the first injectable $\mathrm{Cu}(\mathrm{DDC})_{2}$ formulation is that the synthesis reaction to form $\mathrm{Cu}(\mathrm{DDC})_{2}$ can be completed in liposomes of different lipid compositions and the environment within the liposome can be controlled. As it is possible that the efficacy of $\mathrm{Cu}(\mathrm{DDC})_{2}$ may be enhanced through strategies that enhance its circulation lifetime, a number of strategies were pursued to gain an understanding of the factors influencing $\mathrm{Cu}(\mathrm{DDC})_{2}$ retention in the liposomes. As the in vitro $\mathrm{Cu}(\mathrm{DDC})_{2}$ assay measuring the stability of the $\mathrm{Cu}(\mathrm{DDC})_{2}$ formulation proved to be a poor predictor of in vivo stability, we chose to focus on an in vivo assay where plasma levels of copper or $\mathrm{Cu}(\mathrm{DDC})_{2}$ were measured $30 \mathrm{~min}$ after iv administration into mice. This single time point assay allowed us to assess how changes in the formulation impacted the stability of the injected $\mathrm{Cu}(\mathrm{DDC})_{2}$ formulation. These results are summarized in Figures 5 and 6. First $\mathrm{Cu}(\mathrm{DDC})_{2}$, was synthesized in DSPC/Chol $(55: 45)$ liposomes, which were prepared to contain copper sulfate or $\mathrm{Cu}$-gluconate and, in addition, the $\mathrm{Cu}(\mathrm{DDC})_{2}$-to-lipid ratios were varied in these formulations to determine if the amount of entrapped $\mathrm{Cu}(\mathrm{DDC})_{2}$ affected drug retention. As noted in Figure 5A, the synthesis of $\mathrm{Cu}(\mathrm{DDC})_{2}$ inside the DSPC/Chol liposomes was similar when the liposomes were prepared with $\mathrm{Cu}$-gluconate or copper sulfate. When evaluating the effect of copper salt on the plasma levels of $\mathrm{Cu}(\mathrm{DDC})_{2} 30 \mathrm{~min}$ after injection (Figure 5B, 1 st and 4th bar) it can be concluded that use of $\mathrm{Cu}$-gluconate had no impact on $\mathrm{Cu}(\mathrm{DDC})_{2}$ elimination. These $\mathrm{Cu}(\mathrm{DDC})_{2}$ formulations were also prepared such that selected formulations had lower $\mathrm{Cu}$ (DDC) 2 -to-lipid ratios (Figure 5B, 2nd, 3rd, and 5th column). These formulations exhibited plasma copper levels comparable to the formulations with the higher $\mathrm{Cu}(\mathrm{DDC})_{2}$-tolipid ratios. The elimination of liposomal lipid was unaffected by the formulation changes described above.

When preparing the $\mathrm{Cu}(\mathrm{DDC})_{2}$ formulation using $300 \mathrm{mM}$ copper sulfate, it is assumed that the internal $\mathrm{pH}$ of the liposome is 3.5 (the $\mathrm{pH}$ of the copper solution used when making the liposomes). To determine whether the $\mathrm{pH}$ within the liposome affects $\mathrm{Cu}(\mathrm{DDC})_{2}$ elimination we added the monovalent $\mathrm{K}^{+}$ion ionophore nigericin prior to $\mathrm{Cu}(\mathrm{DDC})_{2}$ synthesis inside the liposomes. Nigericin facilitates the exchange of $\mathrm{K}^{+}$ions in exchange for $\mathrm{H}^{+}$. Thus, $\mathrm{CuSO}_{4}^{-}$ liposomes were exchanged into a $\mathrm{KCl}$-Histidine-containing buffer (see Methods) and subsequently nigericin was added. As noted in Figure $5 \mathrm{C}$, the formation of $\mathrm{Cu}(\mathrm{DDC})_{2}$ inside the DSPC/Chol liposomes was not affected by the change in external buffer or the addition of nigericin. Following iv administration into mice, the plasma copper levels $30 \mathrm{~min}$ after administration were comparable for the nigericin formulation and the formulation prepared without nigericin (Figure 5D). This suggests that an increase in $\mathrm{pH}$ within the liposomes has no impact on the stability of the injected formulation.

To assess how liposomal lipid composition influences the in vivo elimination of intravenously injected $\mathrm{Cu}(\mathrm{DDC})_{2}$, we evaluated $\mathrm{Cu}(\mathrm{DDC})_{2}$ formulations prepared in, 1) Cholcontaining liposomes DSPC/Chol (55:45) and SM/Chol (55:45), 2) Chol-free liposomes (DSPC/DSPE-PEG ${ }_{2000}(95: 5)$ and SM/DSPE-PEG $2000(95: 5)$ ), as well as 3) charged liposomes anionic (DSPC/DSPG/Chol (70:20:10) and cationic (DSPC/DSPG/Chol (70:20:10)). These studies (summarized in Figure 6) used plasma $\mathrm{Cu}(\mathrm{DDC})_{2}$ levels determined 30 min following iv administration as a measure of whether changes in lipid composition could engender decreases in $\mathrm{Cu}(\mathrm{DDC})_{2}$ elimination. Although not shown, the ability to synthesize $\mathrm{Cu}(\mathrm{DDC})_{2}$ in the different liposomal formulations was not affected by liposomal lipid composition. As indicated in Figure 6 (3rd and 6th bar) the only formulations 

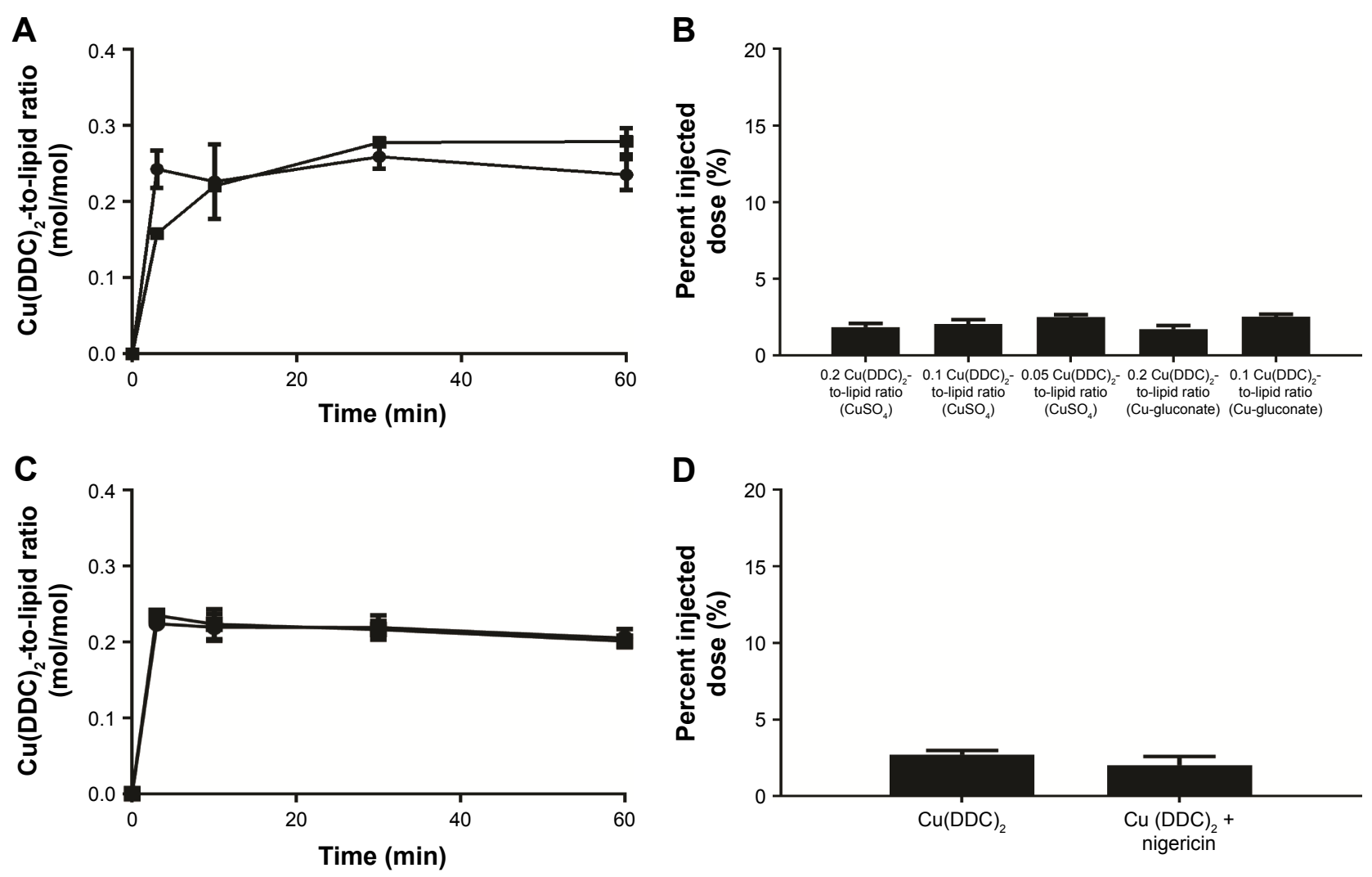

Figure 5 Examining the role of factors within the DSPC/Chol liposomes that may affect $\mathrm{Cu}(\mathrm{DDC})_{2}$ levels in the plasma compartment 30 min after administration. Notes: (A) Preparation of $\mathrm{Cu}(\mathrm{DDC})_{2}$ inside DSPC/Chol (55:45) liposomes containing either $\mathrm{CuSO}_{4}\left({ }^{\bullet}\right)$ or $\mathrm{Cu}$-gluconate ( $\bullet$ ) as a function of time at $25^{\circ} \mathrm{C}$ in $\mathrm{SH}$ buffer. (B) The percent of injected $\mathrm{Cu}(\mathrm{DDC})_{2}$ dose administered intravenously to $\mathrm{CD}-\mathrm{I}$ mice $(\mathrm{n}=4)$ remaining in the plasma $30 \mathrm{~min}$ after injection. The formulations were prepared at different $\mathrm{Cu}(\mathrm{DDC})_{2}$-to-lipid ratios $\left(0.2,0.1\right.$, and 0.05 , mol:mol) and prepared using liposomes with encapsulated $\mathrm{CuSO}_{4}$ or $\mathrm{Cu}$-gluconate buffers. Copper levels were measured by AAS and, after subtraction of background plasma copper levels, these levels were used as a surrogate for $\mathrm{Cu}(\mathrm{DDC})_{2}$. (C) Formation of $\mathrm{Cu}(\mathrm{DDC})_{2}$ inside DSPC/ Chol (55:45) liposomes containing $\mathrm{CuSO}_{4}$ with $(-)$ or without $(\bullet)$ nigericin as a function of time at $25^{\circ} \mathrm{C}$. The external buffer for these liposomes was $\mathrm{KCl}(150 \mathrm{mM})$ and Histidine $(20 \mathrm{mM})$. (D) The percent injected dose of $\mathrm{Cu}(\mathrm{DDC})_{2}$ injected into $\mathrm{CD}-\mathrm{I}$ mice $(\mathrm{n}=4)$ remaining after 30 min following iv administration of $\mathrm{Cu}(\mathrm{DDC})_{2}$ prepared in DSPC/Chol liposomes in the presence and absence of nigericin. Copper levels were measured by AAS and, after subtraction of background plasma copper levels, these levels were used as a surrogate for $\mathrm{Cu}(\mathrm{DDC})_{\mathrm{D}}$. For panels $\mathrm{A}$ and $\mathrm{C}, \mathrm{n}=3$ replicate experiments. In panels $\mathrm{A}$ and $\mathrm{C}$ if the error bars are not visible then the error is within the size of the symbol used. For Panels $B$ and $D, n=4$ mice per group. All data are plotted as mean \pm standard error of the mean.

Abbreviations: AAS, atomic absorption spectroscopy; Chol, cholesterol; DDC, diethyldithiocarbamate; DSPC, distearoyl-sn-glycero-3-phosphocholine; iv, intravenous; SH, sucrose HEPES.

that exhibited significantly higher levels of $\mathrm{Cu}(\mathrm{DDC})_{2}$ in the plasma when compared to $\mathrm{Cu}(\mathrm{DDC})_{2}$ formulated in $\mathrm{DSPC} /$ Chol liposomes were the DSPC/DSPE-PEG ${ }_{2000}$ and DSPC/ DSPG/Chol formulations. These retained $20.8 \%$ and $11.3 \%$ of the injected copper dose in the plasma compartment at $30 \mathrm{~min}$, respectively. The DSPC/DSPE-PEG 2000 formulation showed the highest plasma copper levels, a nearly 7 fold increase over that measured for animals given $\mathrm{Cu}(\mathrm{DDC})_{2}$ formulated in DSPC/Chol liposomes. For this reason, we focused the remaining studies on $\mathrm{Cu}(\mathrm{DDC})_{2}$ formulations prepared in the DSPC/DSPE-PEG 2000 liposomes.

\section{Characterizing $\mathrm{Cu}(\mathrm{DDC})_{2}$, prepared in DSPC/DSPE-PEG 2000 (95:5) liposomes}

To generate the data shown in Figure 6, the ability to create $\mathrm{Cu}(\mathrm{DDC})_{2}$ in liposomes prepared of different lipid compositions needed to be determined. The formation of $\mathrm{Cu}(\mathrm{DDC})_{2}$ in DSPC/DSPE-PEG ${ }_{2000}(95: 5)$ liposomes is illustrated by the data shown in Figure 7. When incubated at $25^{\circ} \mathrm{C}$, a $\mathrm{Cu}(\mathrm{DDC})_{2}$-to-lipid ratio of 0.2 (molar ratio) is achieved within 10 min following addition of DDC to the copper-containing liposomes (Figure 7A, filled squares). DDC enters the liposome through passive diffusion across the liposomal lipid bilayer. As DDC is a relatively small molecule $(171 \mathrm{~g} / \mathrm{mol})$ it can cross the lipid bilayer rapidly, even when the incubation temperature was reduced to $4^{\circ} \mathrm{C}$. It should be noted that the rate of $\mathrm{Cu}(\mathrm{DDC})_{2}$ formation at $4^{\circ} \mathrm{C}$ in the DSPC/DSPE-PEG 2000 liposomes was slower than that observed in DSPC/Chol liposomes. This is reflected by the data summarized in Figure 7B where the $\mathrm{Cu}(\mathrm{DDC})_{2}$-to-lipid ratio for $\mathrm{DSPC} / \mathrm{Chol}$ and $\mathrm{DSPC} /$ DSPE-PEG $_{2000}$ liposomes measured after a $1 \mathrm{~h}$ incubation at 


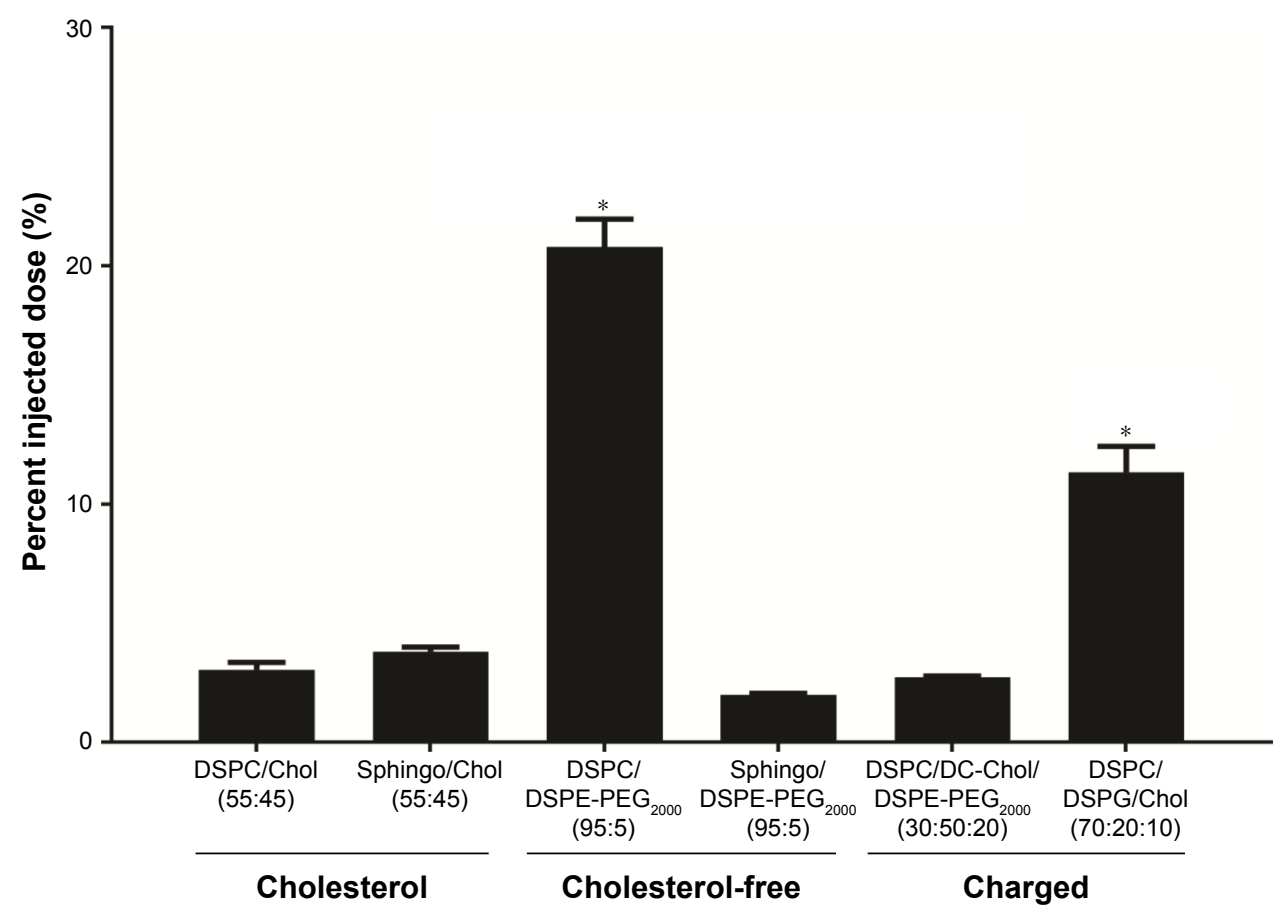

Figure 6 Examining the role of lipid composition on $\mathrm{Cu}(\mathrm{DDC})_{2}$ levels in the plasma compartment 30 min after administration.

Notes: Liposomes composed of DSPC/Chol (55:45), SM/Chol (55:45), DSPC/DSPE-PEG ${ }_{2000}$ (95:5), SM/DSPE-PEG ${ }_{2000}$ (95:5), DSPC/DC-Chol/DSPE-PEG 2000 (30:50:20), and DSPC/DSPG/Chol (70:20:10) were prepared in unbuffered $300 \mathrm{mM} \mathrm{CuSO}_{4}$. $\mathrm{Cu}(\mathrm{DDC})_{2}$ was synthesized in these liposomes to achieve a final $\mathrm{Cu}(\mathrm{DDC})_{2}$-to-lipid ratio of 0.2 (mol:mol) and subsequently injected intravenously into CD-I mice $(\mathrm{n}=4)$ at $15 \mathrm{mg} / \mathrm{kg}$. The plasma levels of $\mathrm{Cu}(\mathrm{DDC})_{2}$ were measured $30 \mathrm{~min}$ after administration. Copper levels were measured by AAS and, after subtraction of background plasma copper levels, these levels were used as a surrogate for Cu(DDC). "**" indicates statistically significant difference $(P>0.05)$ when $\mathrm{Cu}(\mathrm{DDC})_{2}$ levels in the plasma were compared to the levels obtained after injecting $\mathrm{Cu}(\mathrm{DDC})_{2}$ in $\mathrm{DSPC} / \mathrm{Chol}$ liposomes (first column). Significance was determined by a one-way analysis of variance followed by Tukey's post hoc test. For each lipid composition, $n=4$ mice per group. All data are plotted as mean \pm standard error of the mean.

Abbreviations: AAS, atomic absorption spectroscopy; Chol, cholesterol; DDC, diethyldithiocarbamate; DSPC, distearoyl-sn-glycero-3-phosphocholine; SM, sphingomyelin; DSPE-PEG ${ }_{2000}$, I,2-distearoyl-sn-glycero-3-phos-phoethanolamine-n-(carboxy(polyethylene glycol)-2000); DC, 3ß-(N-(N', N'-dimethylaminoethane)-carbamoyl).

$4{ }^{\circ} \mathrm{C}$ (filled bars) suggests that $80 \%$ and $50 \%$ of the encapsulated $\mathrm{Cu}$ is becoming complexed with DDC over the 60 min incubation time frame, respectively. Cryo-electron microscopy was performed on the DSPC/DSPE-PEG ${ }_{2000}$ liposomes before and after $\mathrm{Cu}(\mathrm{DDC})_{2}$ synthesis. As illustrated in Figure $7 \mathrm{C}$, there is no visible difference between the liposomes with encapsulated copper sulfate and those with encapsulated $\mathrm{Cu}(\mathrm{DDC})_{2}$.

Following iv administration of $\mathrm{Cu}(\mathrm{DDC})_{2}$ formulated in the DSPC/DSPE-PEG ${ }_{2000}$ liposomes, there was about $70 \%$ of the injected lipid dose in the plasma compartment at $4 \mathrm{~h}$. In contrast, only $5 \%$ of the injected $\mathrm{Cu}(\mathrm{DDC})_{2}$ was detected (Figure 7D). This is reflected in the change in the $\mathrm{Cu}$ (DDC) $)_{2}$-to-lipid ratio (molar), which indicates that there was $90 \%$ loss of the $\mathrm{Cu}(\mathrm{DDC})_{2}$ from the DSPC/DSPE$\mathrm{PEG}_{2000}$ liposomes within $4 \mathrm{~h}$ after injection (Figure $7 \mathrm{E}$ ). Although $\mathrm{Cu}(\mathrm{DDC})_{2}$ was still eliminated rapidly from the plasma compartment following injection of the formulation prepared in DSPC/DSPE-PEG ${ }_{2000}$ liposomes, this formulation retained $\mathrm{Cu}(\mathrm{DDC})_{2}$ significantly better than the $\mathrm{DSPC} /$ Chol liposomes. The plasma $\mathrm{AUC}_{(0-\infty)}$ for $\mathrm{Cu}(\mathrm{DDC})_{2}$ inside
DSPC/Chol (55:45) liposomes was found to be $4.6 \mu \mathrm{g} \cdot \mathrm{h} / \mathrm{mL}$ while that of $\mathrm{Cu}(\mathrm{DDC})_{2}$ inside of DSPC/DSPE-PEG ${ }_{2000}(95: 5)$ liposomes was found to be $19.3 \mu \mathrm{g} \mathrm{h} / \mathrm{mL}$; representing a 4.2-fold increase in $\mathrm{AUC}_{(0-\infty)}$.

\section{Therapeutic activity of $\mathrm{Cu}(\mathrm{DDC})_{2}$ prepared in DSPC/DSPE-PEG ${ }_{2000}(95: 5)$ liposomes}

To determine if the 4.2-fold increase in $\mathrm{AUC}_{(0-\infty)}$ achieved when using $\mathrm{Cu}(\mathrm{DDC})_{2}$ formulated in $\mathrm{DSPC} / \mathrm{DSPE} \mathrm{PEG}_{2000}$ affected therapeutic activity, mice with established MV-4-11 tumors were treated with this $\mathrm{Cu}(\mathrm{DDC})_{2}$ formulation and the activity was compared to animals treated with $\mathrm{Cu}(\mathrm{DDC})_{2}$ prepared in DSPC/Chol liposomes. As indicated above, the MTD of $\mathrm{Cu}(\mathrm{DDC})_{2}$ prepared in DSPC/Chol liposomes was determined to be $8 \mathrm{mg} / \mathrm{kg}$ when using the $\mathrm{M}, \mathrm{W}, \mathrm{F} \times 2$ schedule. $\mathrm{Cu}(\mathrm{DDC})_{2}$ prepared in DSPC/DSPE-PEG ${ }_{2000}$ liposomes was better tolerated, and the MTD of this formulation was determined to be $12.5 \mathrm{mg} / \mathrm{kg}$ when given via the $\mathrm{M}, \mathrm{W}$, $\mathrm{F} \times 2$ schedule. To assess efficacy, $\mathrm{Cu}(\mathrm{DDC})_{2}$ prepared in DSPC/DSPE-PEG ${ }_{2000}$ liposomes was administered (M, W, 
A

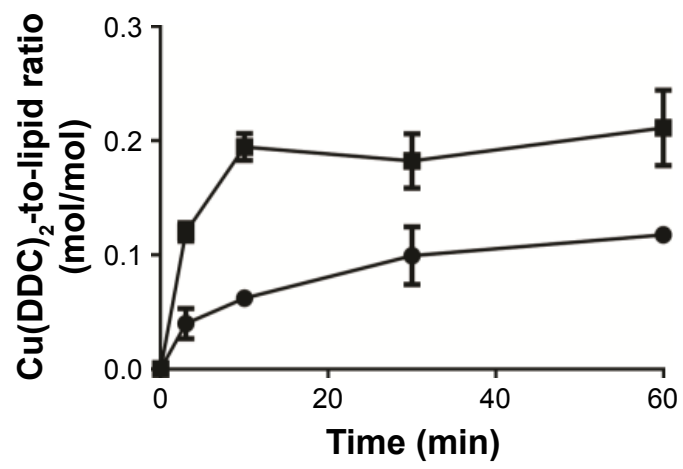
C $\quad 300 \mathrm{mM} \mathrm{CuSO}_{4}$
liposomes

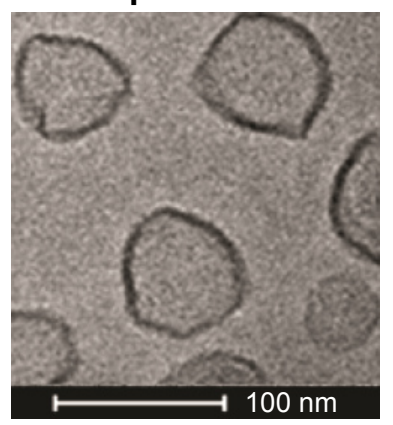

B
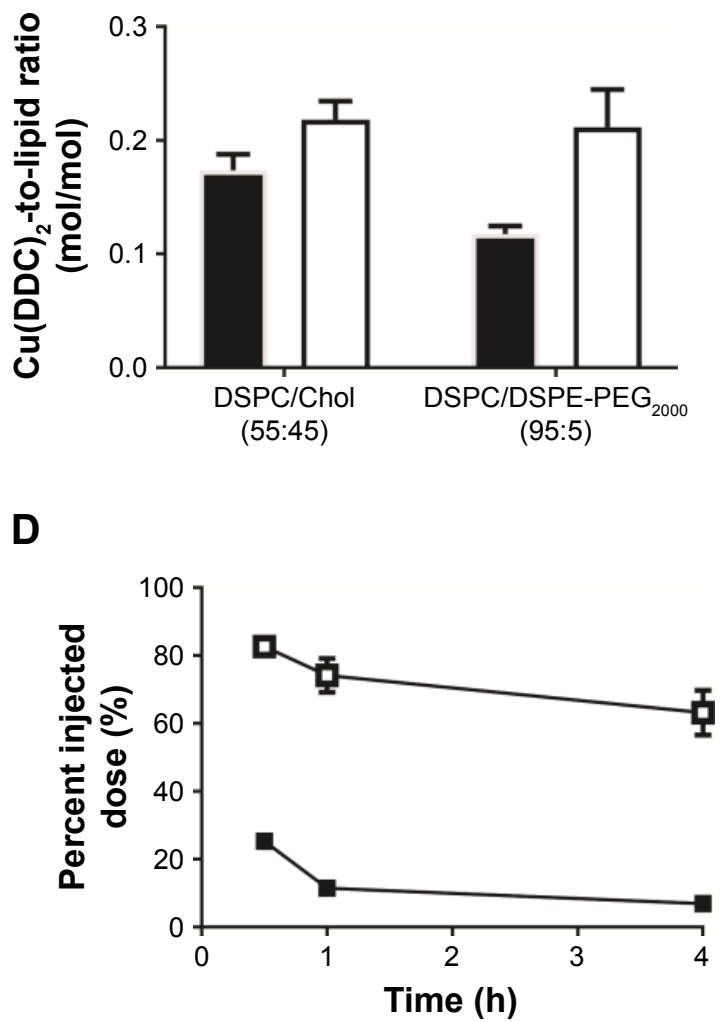

\section{E}

D

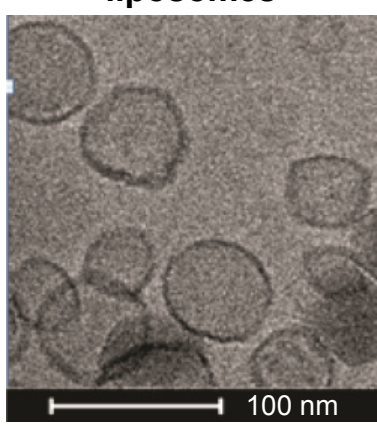

\section{$\mathrm{Cu}(\mathrm{DDC})_{2}$} liposomes

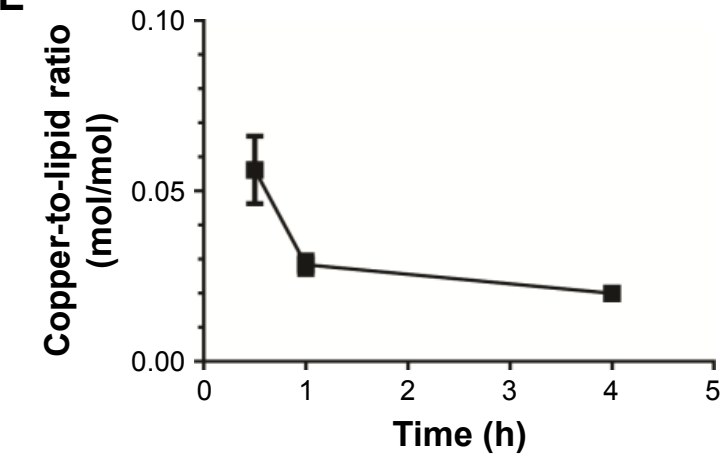

Figure 7 Characterizing $\mathrm{Cu}(\mathrm{DDC})_{2}$, prepared inside DSPC/DSPE-PEG ${ }_{2000}$ (95:5) liposomes.

Notes: (A) DSPC/DSPE-PEG ${ }_{2000}$ liposomes prepared in $300 \mathrm{mM}$ unbuffered CuSO, were incubated at $4^{\circ} \mathrm{C}(\bullet)$ or $25^{\circ} \mathrm{C}(\square)$ with DDC, and the amount of $\mathrm{Cu}(\mathrm{DDC})_{2}$

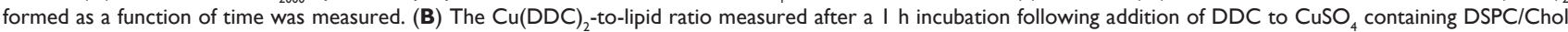

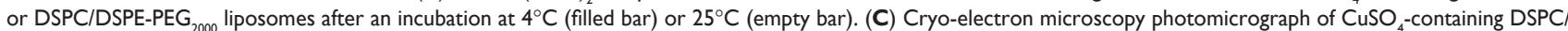
DSPE-PEG 2000 liposomes and $\mathrm{Cu}(\mathrm{DDC})_{2}$ prepared in the same liposomes. (D) $\mathrm{Cu}(\mathrm{DDC})_{2}$ prepared in DSPC/DSPE-PEG 2000 liposomes were injected into $\mathrm{CD}-\mathrm{I}$ mice $(\mathrm{n}=4)$ at $15 \mathrm{mg} / \mathrm{kg}$ and mice were euthanized at $0.5, \mathrm{I}$, and $4 \mathrm{~h}$. Plasma concentration of $\mathrm{Cu}(\mathrm{DDC})_{2}$ and liposomal lipid were determined and the \% injected dose of $\mathrm{Cu}(\mathrm{DDC})_{2}(\mathbf{m})$ and liposomal lipid $(\square)$ was calculated at the indicated time points. $(E) \mathrm{Cu}(\mathrm{DDC})_{2}$-to-lipid ratios were calculated based on the data provided in panel $\mathrm{D}$. All data are plotted as mean \pm standard error of the mean; $n=3$ replicate experiments for panel $A / B$ and $n=4$ mice per group in panel $D$ and $E$.

Abbreviations: Chol, cholesterol; DDC, diethyldithiocarbamate; DSPC, distearoyl-sn-glycero-3-phosphocholine; DSPE-PEG 2000 , I,2-distearoyl-sn-glycero-3-phosphoethanolamine-n-(carboxy(polyethylene glycol)-2000).

$\mathrm{F} \times 2$ schedule) at 8 and $12.5 \mathrm{mg} / \mathrm{kg}$. The injected liposomal lipid doses were 46 and $63 \mathrm{mg} / \mathrm{kg}$, respectively. When $\mathrm{Cu}(\mathrm{DDC})_{2}$ was prepared in DSPC/Chol liposomes, the dose of $\mathrm{Cu}(\mathrm{DDC})_{2}$ was $8 \mathrm{mg} / \mathrm{kg}$ and the liposomal lipid dose was $50 \mathrm{mg} / \mathrm{kg}$. Mice bearing MV-4-11 tumors were treated 12 days after tumor cell inoculation and tumor growth was monitored over time (see Methods). The results, summarized in Figure 8, indicated that all $\mathrm{Cu}(\mathrm{DDC})_{2}$-treated animals showed a statistically significant decrease in tumor volume when compared to vehicle-treated animals (Figure 8A). When comparing tumor size on day 33 , the day when some control mice were euthanized because of large tumor sizes (our animal care protocol specifies that the humane endpoint for animals with sc tumors is when the tumor volume is greater 

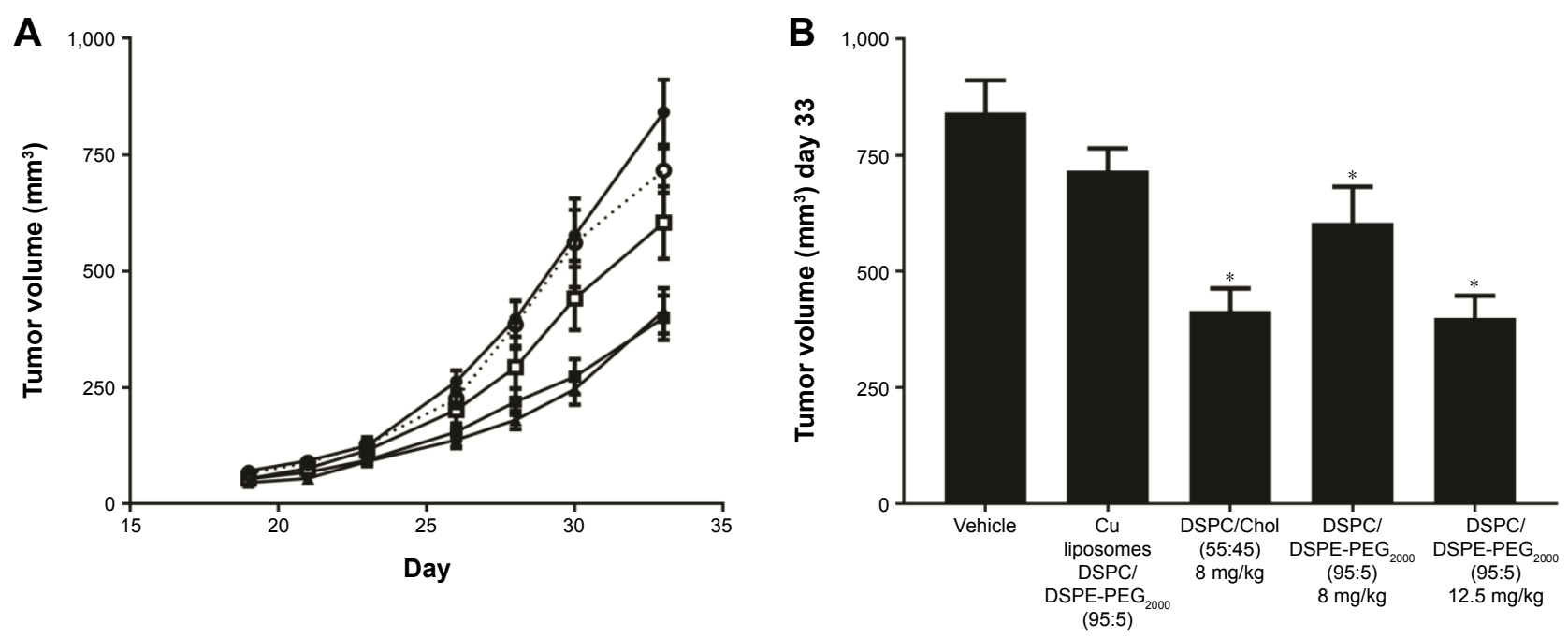

Figure $8 \mathrm{Cu}(\mathrm{DDC})_{2}$ antitumor activity determined in mice bearing established sc MV-4-II tumors.

Notes: The $1 \times 10^{6}$ MV-4-II cells were inoculated subcutaneously into RAG-2M mice and were treated intravenously with vehicle- (- - -), copper-containing DSPC/DSPE$\mathrm{PEG}_{2000}$ (95:5) liposomes (-o-, $1.7 \mathrm{mg} / \mathrm{kg}$ copper, $63 \mathrm{mg} / \mathrm{kg} \mathrm{lipid),} 8 \mathrm{mg} / \mathrm{kg} \mathrm{Cu}(\mathrm{DDC})_{2}$ prepared in DSPC/Chol liposomes (- $\mathbf{\Delta}-, 8 \mathrm{mg} / \mathrm{kg} \mathrm{Cu}(\mathrm{DDC})_{2}$ and $50 \mathrm{mg} / \mathrm{kg} \mathrm{lipid),} 8 \mathrm{mg} / \mathrm{kg}$ $\mathrm{Cu}(\mathrm{DDC})_{2}$ prepared in DSPC/DSPE-PEG ${ }_{2000}$ liposomes (- $\square-, 8 \mathrm{mg} / \mathrm{kg} \mathrm{Cu}(\mathrm{DDC})_{2}, 40 \mathrm{mg} / \mathrm{kg}$ lipid) or $12.5 \mathrm{mg} / \mathrm{kg}$ Cu(DDC), prepared in DSPC/DSPE-PEG 2000 liposomes (- -, $12.5 \mathrm{mg} / \mathrm{kg} \mathrm{Cu}(\mathrm{DDC})_{2}, 63 \mathrm{mg} / \mathrm{kg}$ lipid) using a M, W, F $\times 2$ schedule. (A) Tumor volumes were measured 3 times a week and were plotted as mean \pm SEM. (B) Mean tumor volume \pm SEM determined on day 33 (the humane endpoint for vehicle-treated animals). “*” Indicates statistically significant difference $P>0.05$; one-way analysis of variance followed by Tukey's post hoc test.

Abbreviations: Chol, cholesterol; DDC, diethyldithiocarbamate; DSPC, distearoyl-sn-glycero-3-phosphocholine; M, W, F $\times 2$, Monday, Wednesday, and Friday for 2 weeks; SEM, standard error of the mean; DSPE-PEG ${ }_{2000}$, I,2-distearoyl-sn-glycero-3-phos-phoethanolamine-n-(carboxy(polyethylene glycol)-2000); sc, subcutaneous.

than $\left.800 \mathrm{~mm}^{3}\right)$, animals treated with $\mathrm{Cu}(\mathrm{DDC})_{2}$ prepared in DSPC/Chol liposomes had tumors that were $1 / 2$ the size of control animals. At the same dose of $\mathrm{Cu}(\mathrm{DDC})_{2}$ prepared in DSPC/DSPE-PEG $_{2000}$ liposomes, the tumor size was only $28 \%$ smaller than the tumors from vehicle-treated mice, suggesting that at equivalent doses, the DSPC/DSPE-PEG ${ }_{2000}$ formulation was less effective. However, when efficacy was compared at the MTD of each formulation, the antitumor activity was equivalent (Figure 8B). Both formulations were able to delay progression of tumor growth in this model, but we conclude that further formulation changes will be required to optimize $\mathrm{Cu}(\mathrm{DDC})_{2}$ activity.

\section{Discussion}

DSF and copper have been the focus of many oncology-focused research programs and clinical trials because of the surprising anticancer activity observed when the 2 components are given together in vitro. ${ }^{1,3,34}$ This discovery exemplified an opportunity to repurpose DSF, an agent with over 60 years of clinical use in the context of alcohol addiction. ${ }^{13,35,36} \mathrm{We}$, as well as others, have previously shown that the cytotoxicity of DSF and $\mathrm{Cu}$ is attributed to the formation of a $\mathrm{Cu}(\mathrm{DDC})_{2}$ complex. ${ }^{11,19}$ Attempts have been made to prepare the complex in vivo by administering DSF and $\mathrm{Cu}$ (usually given as $\mathrm{Cu}$-gluconate) separately. However, the PK and distribution behaviors of copper and DSF are remarkably different and this has contributed to the lack of success using this approach. Thus, while the DSF/Cu combination shows remarkable activity in vitro this has not translated in vivo. To date, the therapeutic activity of the $\mathrm{Cu}(\mathrm{DDC})_{2}$ complex has not been directly evaluated in vivo owing to the insolubility of the complex in aqueous solutions. We solved this challenge by synthesizing $\mathrm{Cu}(\mathrm{DDC})_{2}$ inside liposomes. ${ }^{19}$ These methods rely on liposomes serving as nano-scale reaction vessels to support the synthesis of $\mathrm{Cu}(\mathrm{DDC})_{2}$ when $\mathrm{DDC}$ is added to the outside of copper sulfate-containing liposomes. To our knowledge, we are the first to characterize the anticancer activity of $\mathrm{Cu}(\mathrm{DDC})_{2}$ following iv administration.

We have previously shown that $\mathrm{Cu}(\mathrm{DDC})_{2}$, was cytotoxic to cancer cells but did not have any effect in healthy bronchial epithelial cells in vitro. ${ }^{19}$ Consistent with other in vitro studies, ${ }^{21,37}$ we have confirmed that the primary mechanism of action for $\mathrm{Cu}(\mathrm{DDC})_{2}$ is through proteosome inhibition (Figure 2). Flow cytometric studies suggested that cellcycle arrest does not contribute to $\mathrm{Cu}(\mathrm{DDC})_{2}$ cytotoxicity. Interestingly, DSF and copper have been reported to be effective against brain tumor-initiating cells (BTICs) that are senescent. ${ }^{3,33,38}$ Thus, the ability of $\mathrm{Cu}(\mathrm{DDC})_{2}$ to be effective regardless of cell-cycle stage may contribute to the drug's ability to kill BTICs. Our in vitro studies (Figure 2) indicate that the activity of $\mathrm{Cu}(\mathrm{DDC})_{2}$ is not mediated by the generation of ROS, that is, no increase in ROS production 
was observed when cells were incubated with $\mathrm{Cu}(\mathrm{DDC})_{2}$. Previously Tawari et al noted an increase in ROS when DSF and copper were added to cell media but not when DDC and copper were added. ${ }^{20}$ The authors suggested that ROS generation was a by-product produced that occurred when $\mathrm{DSF}$ and $\mathrm{Cu}$ were mixed in vitro. However, ROS would not be generated if using preformed $\mathrm{Cu}(\mathrm{DDC})_{2}$ complex in liposomes, as done in the studies reported here. This was done to help avoid precipitation of $\mathrm{Cu}(\mathrm{DDC})_{2}$ under conditions where the complex is added as a DMSO-solubilized form. The in vitro results suggested that $\mathrm{Cu}(\mathrm{DDC})_{2}$ prepared in DSPC/Chol liposomes was available to the cells in culture, a preliminary indication that $\mathrm{Cu}(\mathrm{DDC})_{2}$ dissociated from the liposomes.

The in vivo studies completed with $\mathrm{Cu}(\mathrm{DDC}){ }_{2}$ produced in DSPC/Chol liposomes indicated that the drug was rapidly eliminated from plasma after iv administration ( $>90 \%$ of the injected dose was eliminated within $15 \mathrm{~min}$, Figure 3) and confirmed that $\mathrm{Cu}(\mathrm{DDC})_{2}$ rapidly dissociated from the liposomes after administration. This was surprising, in part, because the in vitro studies shown in Figure $1 \mathrm{C}$ suggested that the $\mathrm{Cu}(\mathrm{DDC})_{2}$ formulations were stable when prepared in the DSPC/Chol liposomes. $\mathrm{Cu}(\mathrm{DDC})_{2}$ prepared in $\mathrm{DSPC} / \mathrm{Chol}$ liposomes was therapeutically active. When administered at its MTD, the effects resulted in a delay in tumor progression. This was determined in an sc model as well as an intracranial model where $\mathrm{Cu}(\mathrm{DDC})_{2}$ was given by $\mathrm{CED}$ directly to the site of tumor cell inoculation (Figure 4). We concluded that the therapeutic activity of $\mathrm{Cu}(\mathrm{DDC})_{2}$ may be limited because of its rapid elimination from the plasma compartment and we thought that this could be addressed. An advantage of the technology used here is that the composition of the liposome in which the $\mathrm{Cu}(\mathrm{DDC})_{2}$, is formed can be changed to improve the in vivo stability of the resulting formulation. When $\mathrm{Cu}(\mathrm{DDC})_{2}$ was prepared in DSPC/DSPE-PEG ${ }_{2000}$ (Chol-free) liposomes there was an improvement in plasma $\mathrm{Cu}(\mathrm{DDC})_{2}$ levels, which likely equated to an improvement in $\mathrm{Cu}(\mathrm{DDC})_{2}$ retention within the liposome. $\mathrm{Cu}(\mathrm{DDC})_{2}$ prepared in DSPC/ DSPG/Chol liposomes also showed some improved stability in vivo. In both of these examples, it could be argued that the anionic surface charge played a role in improved stability of the formulation..$^{39}$ Alternatively, because the DSPC/DSPG/ Chol liposomes contained only 10\% Chol (a low-Chol formulation), improved $\mathrm{Cu}(\mathrm{DDC})_{2}$ retention could be due to the removal of $\mathrm{Chol}^{40}{ }^{40}$ it is important to note that an increase in drug retention was not seen in the chol-free SM/DSPE$\mathrm{PEG}_{2000}$ formulation. For $\mathrm{Cu}(\mathrm{DDC})_{2}$ prepared in $\mathrm{DSPC} / \mathrm{Chol}$ liposomes, factors such as $\mathrm{Cu}(\mathrm{DDC})_{2}$-to-lipid ratio, choice of entrapped copper salt, and the internal liposomal $\mathrm{pH}$ did not appear to affect the stability of the formulation (Figure 5). The $\mathrm{Cu}(\mathrm{DDC})_{2}$ plasma $\mathrm{AUC}_{(0-\infty)}$ was 4.2-fold higher for the DSPC/DSPE-PEG ${ }_{2000}$ formulation when compared to $\mathrm{Cu}(\mathrm{DDC})_{2}$ prepared in DSPC/Chol liposomes. Although the resulting DSPC/DSPE-PEG ${ }_{2000}$ formulation was better tolerated, its therapeutic activity was not better than the DSPC/Chol formulation (Figure 8). It can be concluded that the decreased plasma elimination rate affects the safety profile of the resultant formulation, but more significant improvements in the stability of the formulation will be needed to enhance the activity of $\mathrm{Cu}(\mathrm{DDC})_{2}$ in vivo.

The $\mathrm{Cu}(\mathrm{DDC})_{2}$ formulations described here do provide some therapeutic benefit, but we believe that the full therapeutic potential of $\mathrm{Cu}(\mathrm{DDC})_{2}$ may only be achieved through careful selection of the appropriate cancer indication and/or by using it in combination with another drug. For example, Lun et al have demonstrated that temozolomide (TMZ) can be used in combination with DSF and copper. ${ }^{33}$ It would be a natural transition to examine if $\mathrm{Cu}(\mathrm{DDC})_{2}$ could be used in combination with TMZ. Also, given a mechanism that involves proteosome inhibition, $\mathrm{Cu}(\mathrm{DDC})_{2}$ may be useful when combined with other drugs known to enhance the activity of known proteasome inhibitors such as bortezomib. In this context, it has been shown that bortezomib acts synergistically with CDK9 kinase inhibitors. ${ }^{41}$ Cvek et al have examined the mechanism by which $\mathrm{Cu}(\mathrm{DDC})_{2}$ inhibits the cellular $26 \mathrm{~S}$ proteosome and have described that this occurs through inhibition of the JAMM domain in the $19 \mathrm{~S}$ proteasome lid, ${ }^{21}$ a site distinct to where bortezomib acts. For this reason $\mathrm{Cu}(\mathrm{DDC})_{2}$ may be effective when used in combination with drugs that work well with bortezomib, or alternatively, $\mathrm{Cu}(\mathrm{DDC})_{2}$ may prove active against bortezomibresistant cancers. ${ }^{42}$

\section{Conclusion}

Herein we disclose the first studies ever to evaluate the anticancer activity of $\mathrm{Cu}(\mathrm{DDC})_{2}$ prepared using a technique that synthesizes $\mathrm{Cu}(\mathrm{DDC})_{2}$ in the core of liposomes. This method solves problems associated with $\mathrm{Cu}(\mathrm{DDC})_{2}$, insolubility and allows for its direct administration. Two formulations were tested in an in vivo MV-4-11 leukemia model and both produced a $\sim 50 \%$ reduction in tumor volume at their respective MTDs when compared to control groups. Additional studies are needed to optimize the therapeutic potential of the $\mathrm{Cu}(\mathrm{DDC})_{2}$ formulations described here. We are particularly interested in establishing its activity in combination with other drugs. 


\section{Acknowledgments}

The authors would like to acknowledge N. Dos Santos and the staff of the Investigational Drug Program at the BC Cancer Agency for their contributions to the toxicity, PK and efficacy studies.

The research described in this original paper was supported by grant funding from the Canadian Cancer Society Research Institute (Award \# 702491 and 705290). Additional funding was obtained from the BC Cancer Foundation and the Centre for Drug Research and Development. AWYL acknowledges financial support from the Canadian Vanier Graduate Scholarship through Canadian Institutes of Health Research.

\section{Disclosure}

The authors report no conflicts of interest in this work.

\section{References}

1. Chen D, Cui QC, Yang HJ, Dou QP. Disulfiram, a clinically used antialcoholism drug and copper-binding agent, induces apoptotic cell death in breast cancer cultures and xenografts via inhibition of the proteasome activity. Cancer Res. 2006;66(21):10425-10433.

2. Doyon G, Zerbato J, Mellors JW, Sluis-Cremer N. Disulfiram reactivates latent HIV-1 expression through depletion of the phosphatase and tensin homolog. Aids. 2013;27(2):F7-F11.

3. Liu P, Brown S, Goktug T, et al. Cytotoxic effect of disulfiram/copper on human glioblastoma cell lines and ALDH-positive cancer-stem-like cells. Brit J Cancer. 2012;107(9):1488-1497.

4. Rae C, Tesson M, Babich JW, Boyd M, Sorensen A, Mairs RJ. The role of copper in disulfiram-induced toxicity and radiosensitization of cancer cells. J Nucl Med. 2013;54(6):953-960.

5. Xing S, Bullen CK, Shroff NS, et al. Disulfiram reactivates latent HIV-1 in a Bcl-2-transduced primary CD4+ T cell model without inducing global T cell activation. $J$ Virol. 2011;85(12):6060-6064.

6. Zhang H, Chen D, Ringler J, et al. Disulfiram treatment facilitates phosphoinositide 3-kinase inhibition in human breast cancer cells in vitro and in vivo. Cancer Res. 2010;70(10):3996-4004.

7. Hothi P, Martins TJ, Chen L, et al. High-throughput chemical screens identify disulfiram as an inhibitor of human glioblastoma stem cells. Oncotarget. 2012;3(10):1124-1136.

8. Papaioannou M, Mylonas I, Kast RE, Bruning A. Disulfiram/ copper causes redox-related proteotoxicity and concomitant heat shock response in ovarian cancer cells that is augmented by auranofin-mediated thioredoxin inhibition. Oncoscience. 2013;1(1): $21-29$

9. Duan L, Shen H, Zhao G, et al. Inhibitory effect of Disulfiram/copper complex on non-small cell lung cancer cells. Biochem Bioph Res Commun. 2014;446(4):1010-1016.

10. Guo X, Xu B, Pandey S, et al. Disulfiram/copper complex inhibiting NFkappaB activity and potentiating cytotoxic effect of gemcitabine on colon and breast cancer cell lines. Cancer Lett. 2010;290(1): 104-113.

11. Lewis DJ, Deshmukh P, Tedstone AA, Tuna F, O'Brien P. On the interaction of copper(II) with disulfiram. Chem Commun (Camb). 2014; 50(87):13334-13337.

12. Cobby J, Mayersohn M, Selliah S. The rapid reduction of disulfiram in blood and plasma. J Pharmacol Exp Ther. 1977;202(3):724-731.

13. Johansson B. A review of the pharmacokinetics and pharmacodynamics of disulfiram and its metabolites. Acta Psychiatr Scand Suppl. 1992;369:15-26.
14. Han J, Liu L, Yue X, Chang J, Shi W, Hua Y. A binuclear complex constituted by diethyldithiocarbamate and copper(I) functions as a proteasome activity inhibitor in pancreatic cancer cultures and xenografts. Toxicol Appl Pharmacol. 2013;273(3):477-483.

15. San Andres MP, Marina ML, Vera S. Spectrophotometric determination of copper(II), nickel(II) and cobalt(II) as complexes with sodium diethyldithiocarbamate in cationic micellar medium of hexadecyltrimethylammonium salts. Talanta. 1994;41(2):179-185.

16. Calvert JG, Simon EH. Effects of the copper chelators diethyldithiocarbamate and bathocuproine sulfonate on interferon and its antiviral state. J Interferon Res. 1990;10(1):13-23.

17. Lakomaa EL, Sato S, Goldberg AM, Frazier JM. The effect of sodium diethyldithiocarbamate treatment on copper and zinc concentrations in rat brain. Toxicol Appl Pharmacol. 1982;65(2):286-290.

18. Moseley HW, Rohwer AG, Moore MC. Use of sodium diethyldithiocarbamate in the determination of minute amounts of copper. Science. 1934;79(2057):507-508.

19. Wehbe M, Anantha M, Backstrom I, et al. Nanoscale reaction vessels designed for synthesis of copper-drug complexes suitable for preclinical development. PLoS One. 2016;11(4):e0153416.

20. Tawari PE, Wang Z, Najlah M, et al. The cytotoxic mechanisms of disulfiram and copper(ii) in cancer cells. Toxicol Res (Camb). 2015;4(6): 1439-1442.

21. Cvek B, Milacic V, Taraba J, Dou QP. Ni(II), Cu(II), and Zn(II) diethyldithiocarbamate complexes show various activities against the proteasome in breast cancer cells. J Med Chem. 2008;51(20):6256-6258.

22. Skrott Z, Cvek B. Diethyldithiocarbamate complex with copper: the mechanism of action in cancer cells. Mini Rev Med Chem. 2012;12(12): 1184-1192.

23. Hope MJ, Bally MB, Webb G, Cullis PR. Production of large unilamellar vesicles by a rapid extrusion procedure - characterization of size distribution, trapped volume and ability to maintain a membrane-potential. Biochim Biophys Acta. 1985;812(1):55-65.

24. Mayer LD, Hope MJ, Cullis PR, Janoff AS. Solute distributions and trapping efficiencies observed in freeze-thawed multilamellar vesicles. Biochim Biophys Acta. 1985;817(1):193-196.

25. Li C, Cui J, Li Y, et al. Copper ion-mediated liposomal encapsulation of mitoxantrone: the role of anions in drug loading, retention and release. Eur J Pharm Sci. 2008;34(4-5):333-344.

26. Belliveau NM, Huft J, Lin PJ, et al. Microfluidic synthesis of highly potent limit-size lipid nanoparticles for in vivo delivery of siRNA. Mol Ther Nucleic Acids. 2012;1:e37.

27. Mathieu D, Lecomte R, Tsanaclis AM, Larouche A, Fortin D. Standardization and detailed characterization of the syngeneic Fischer/F98 glioma model. Can J Neurol Sci. 2007;34(3):296-306.

28. Shi MH, Fortin D, Sanche L, Paquette B. Convection-enhancement delivery of platinum-based drugs and Lipoplatin(TM) to optimize the concomitant effect with radiotherapy in F98 glioma rat model. Invest New Drugs. 2015;33(3):555-563.

29. Pang H, Chen D, Cui QC, Dou QP. Sodium diethyldithiocarbamate, an AIDS progression inhibitor and a copper-binding compound, has proteasome-inhibitory and apoptosis-inducing activities in cancer cells. Int J Mol Med. 2007;19(5):809-816.

30. Colado E, Alvarez-Fernandez S, Maiso P, et al. The effect of the proteasome inhibitor bortezomib on acute myeloid leukemia cells and drug resistance associated with the CD34+ immature phenotype. Haematologica. 2008;93(1):57-66.

31. Messerer CL, Ramsay EC, Waterhouse D, et al. Liposomal irinotecan: formulation development and therapeutic assessment in murine xenograft models of colorectal cancer. Clin Cancer Res. 2004;10(19): 6638-6649.

32. Eisenhauer EA, Therasse P, Bogaerts J, et al. New response evaluation criteria in solid tumours: revised RECIST guideline (version 1.1). Eur $J$ Cancer. 2009;45(2):228-247.

33. Lun XQ, Wells JC, Grinshtein N, et al. Disulfiram when combined with copper enhances the therapeutic effects of temozolomide for the treatment of glioblastoma. Clin Cancer Res. 2016;22(15):3860-3875. 
34. Utah Uo. Phase I study of disulfiram and copper gluconate for the treatment of refractory solid tumors involving the liver. Available from: https://ClinicalTrials.gov/show/NCT00742911. 2008. Accessed March 26, 2017.

35. Borup C, Kaiser A, Jensen E. Long-term Antabuse treatment: tolerance and reasons for withdrawal. Acta Psychiatr Scand Suppl. 1992; 369:47-49

36. Suh JJ, Pettinati HM, Kampman KM, O'Brien CP. The status of disulfiram: a half of a century later. J Clin Psychopharmacol. 2006;26(3) 290-302.

37. Cvek B, Dvorak Z. Targeting of nuclear factor-kappaB and proteasome by dithiocarbamate complexes with metals. Cur Pharm Des. 2007;13(30): 3155-3167.

38. Ouchi R, Okabe S, Migita T, Nakano I, Seimiya H. Senescence from glioma stem cell differentiation promotes tumor growth. Biochem Biophys Res Commun. 2016;470(2):275-281.
39. Allen C, Dos Santos N, Gallagher R, et al. Controlling the physical behavior and biological performance of liposome formulations through use of surface grafted poly(ethylene glycol). Biosci Rep. 2002;22(2): 225-250.

40. Dos Santos N, Cox KA, McKenzie CA, et al. pH gradient loading of anthracyclines into cholesterol-free liposomes: enhancing drug loading rates through use of ethanol. Biochim Biophys Acta. 2004; 1661(1):47-60.

41. Dai Y, Rahmani M, Pei XY, Dent P, Grant S. Bortezomib and flavopiridol interact synergistically to induce apoptosis in chronic myeloid leukemia cells resistant to imatinib mesylate through both Bcr/Abl-dependent and -independent mechanisms. Blood. 2004;104(2):509-518.

42. Malek E, Abdel-Malek MA, Jagannathan S, et al. Pharmacogenomics and chemical library screens reveal a novel SCFSKP2 inhibitor that overcomes bortezomib resistance in multiple myeloma. Leukemia. 2017 31(3):645-653. 


\section{Supplementary materials Glioma cell line cytoxicity}

F98 and U251 cells were grown in DMEM (Thermo Fisher Scientific, Waltham, MA, USA) which was supplemented with $2 \mathrm{mM}$ L-glutamine (Thermo Fisher Scientific) and 10\% fetal bovine serum (Thermo Fisher Scientific) and maintained at $37^{\circ} \mathrm{C}$ and $5 \% \mathrm{CO}_{2}$. Prior to drug treatment, the cells were seeded into 384-well plates and allowed to grow for $24 \mathrm{~h}$. Copper diethyldithiocarbamate $\left(\mathrm{Cu}(\mathrm{DDC})_{2}\right)$ was added for $72 \mathrm{~h}$ and then cells were stained with Hoescht 33342 and ethidium homodimer I for total and dead cell counts, respectively. Cells were imaged using an In Cell Analyzer 2200 (GE Healthcare Life Sciences, Mississauga, ON, Canada) and cell viability was measured based on viable nuclei count.
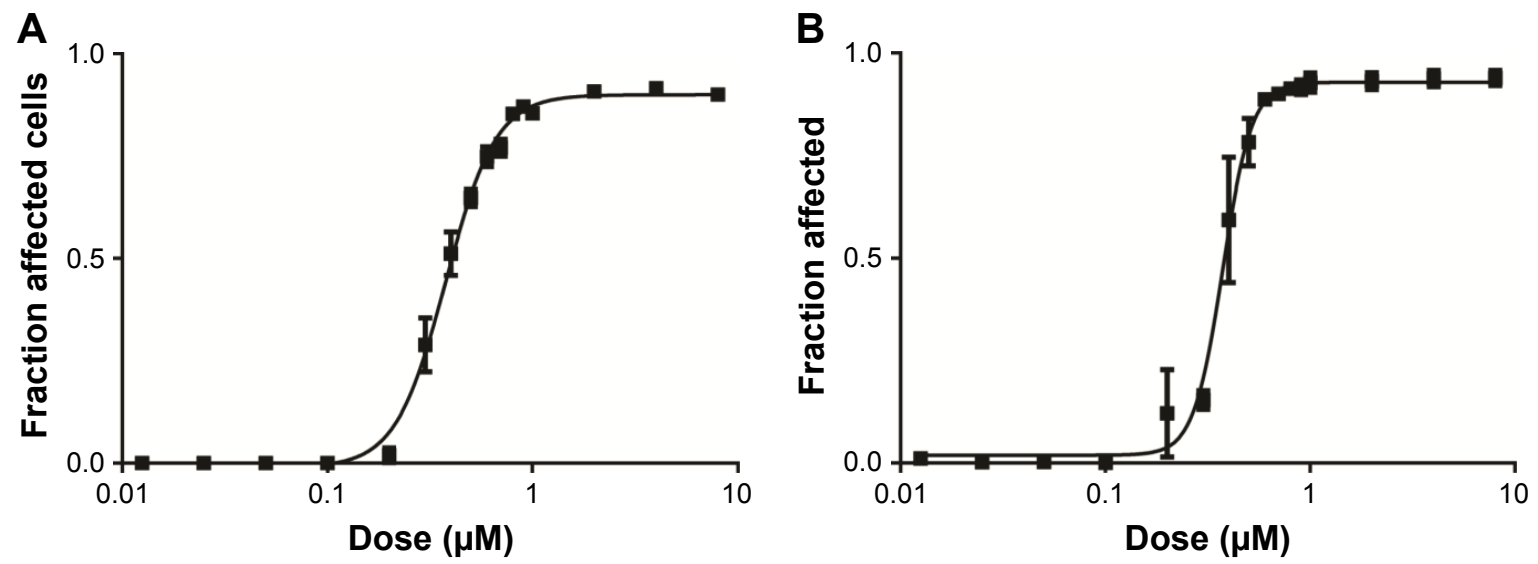

Figure SI Cu(DDC) $)_{2}$ cytoxicity in F98 and U25I glioma cancer cell lines.

Notes: (A, B) Cells were exposed to $\mathrm{Cu}(\mathrm{DDC})_{2}$ (prepared inside DSPC/Chol liposomes) for $72 \mathrm{~h}$. Cell viability was obtained using the In Cell Analyzer where viability was assessed based on loss of plasma membrane integrity $72 \mathrm{~h}$ following treatment; that is, total cell count and dead cell count were determined using Hoechst 33342 and ethidium homodimer staining, respectively. Data is presented as mean \pm standard error of the mean of 3 experiments.

Abbreviations: Chol, cholesterol; DDC, diethyldithiocarbamate; DSPC, 1,2-distearoyl-sn-glycero-3-phosphocholine.

\section{Publish your work in this journal}

The International Journal of Nanomedicine is an international, peerreviewed journal focusing on the application of nanotechnology in diagnostics, therapeutics, and drug delivery systems throughout the biomedical field. This journal is indexed on PubMed Central, MedLine, CAS, SciSearch $®$, Current Contents ${ }^{\circledR} /$ Clinical Medicine,
Journal Citation Reports/Science Edition, EMBase, Scopus and the Elsevier Bibliographic databases. The manuscript management system is completely online and includes a very quick and fair peer-review system, which is all easy to use. Visit http://www.dovepress.com/ testimonials.php to read real quotes from published authors. 